Prepared in cooperation with the Lower Brule Sioux Tribe

\title{
Ground-Survey and Water-Quality Data for Selected Wetlands on or near the Lower Brule Indian Reservation in South Dakota, 2012-13
}

Data Series 949 


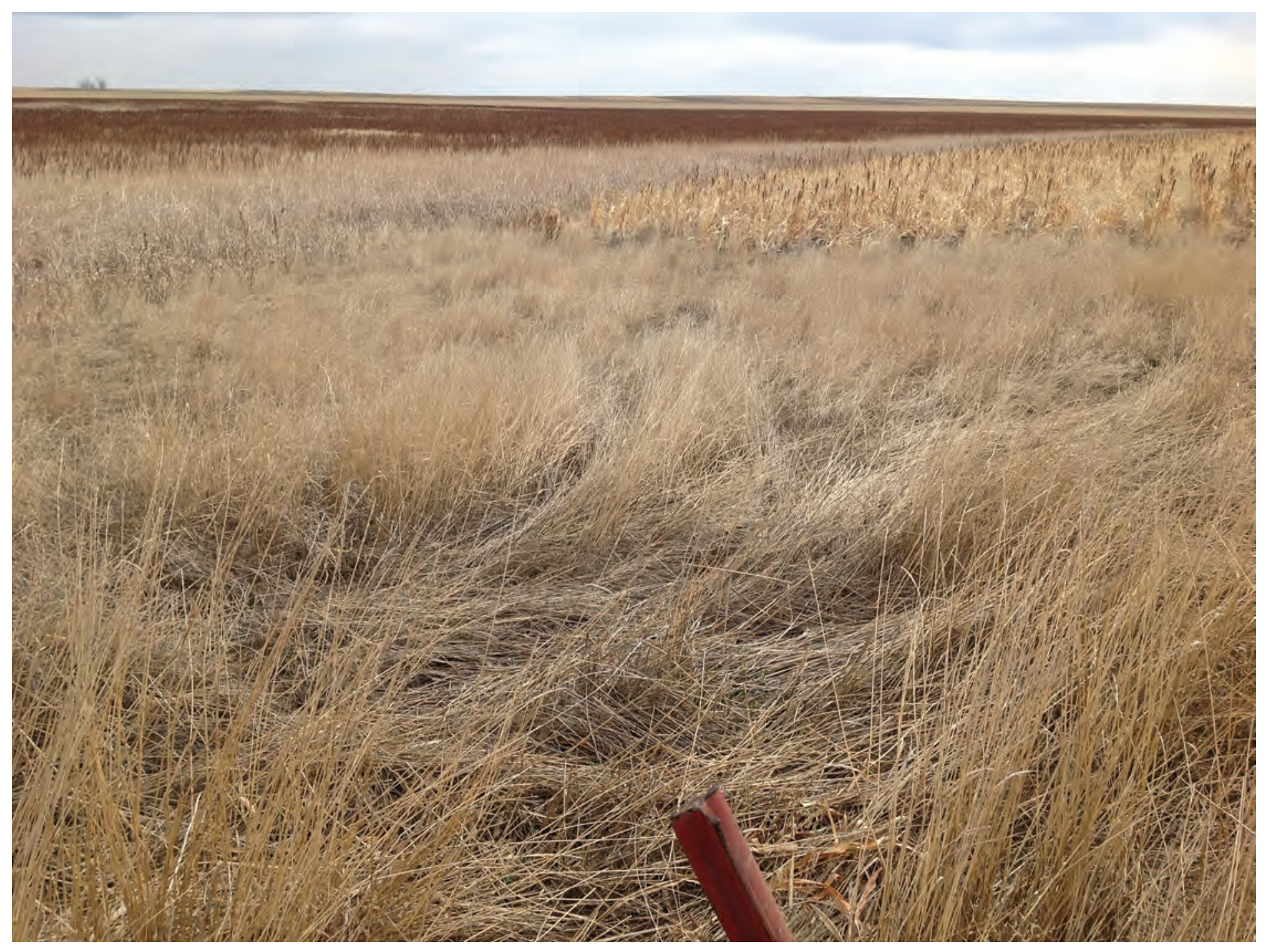

Above. View of wetland vegetation (distant) and food plot (right) at Dorman Slough.

Front cover photograph. Heavy waterfowl and shorebird usage at Miller Pond. 


\section{Ground-Survey and Water-Quality Data for Selected Wetlands on or near the Lower Brule Indian Reservation in South Dakota, 2012-13}

By Kathleen M. Neitzert and Ryan F. Thompson

Prepared in cooperation with the Lower Brule Sioux Tribe

Data Series 949 


\title{
U.S. Department of the Interior SALLY JEWELL, Secretary
}

\section{U.S. Geological Survey \\ Suzette M. Kimball, Acting Director}

\author{
U.S. Geological Survey, Reston, Virginia: 2015
}

For more information on the USGS - the Federal source for science about the Earth, its natural and living resources, natural hazards, and the environment—visit http://www.usgs.gov or call 1-888-ASK-USGS.

For an overview of USGS information products, including maps, imagery, and publications, visit http://www.usgs.gov/pubprod/.

Any use of trade, firm, or product names is for descriptive purposes only and does not imply endorsement by the U.S. Government.

Although this information product, for the most part, is in the public domain, it also may contain copyrighted materials as noted in the text. Permission to reproduce copyrighted items must be secured from the copyright owner.

Suggested citation:

Neitzert, K.M., and Thompson, R.F., 2015, Ground-survey and water-quality data for selected wetlands on or near the Lower Brule Indian Reservation in South Dakota, 2012-13: U.S. Geological Survey Data Series Report 949, 21 p., http://dx.doi.org/10.3133/ds949.

ISSN 2327-638X (online 


\section{Contents}

Abstract
Introduction.
Purpose and Scope
Previous Investigations
Wetlands Classification and Site Selection
Methods
Ground-Survey Methods
Oualite Assurance and Quality Control
Water-Quality Data
Summary.
References Cited.
Appendix 1. Geodatabase for Wetlands Surveyed on or near the
Lower Brule Indian Reservation in South Dakota, 2012-13

\section{Figures}

1. Map showing location of the Lower Brule Indian Reservation in South Dakota and generalized location of selected wetlands investigated for this study .............................2

2. Maps showing primary land, water, and vegetation features for the Dorman Slough wetland parcel ..........................................................................................................

3. Maps showing primary land, water, and vegetation features for the Little Bend Wetlands parcel..

4. Maps showing primary land, water, and vegetation features for the Miller Pond wetland parcel....

5. Maps showing primary land, water, and vegetation features for the Potter Slough

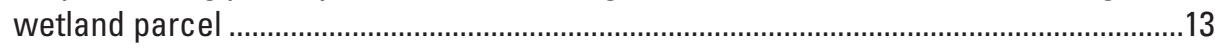

6. Maps showing primary land, water, and vegetation features for the unnamed slough wetland parcel .................................................................................................16

7. Maps showing primary land, water, and vegetation features for the West Brule Community wetland area.

\section{Tables}

1. National Wetland Inventory classifications and areas for wetlands located on the Lower Brule Indian Reservation.

2. National Wetland Inventory classifications and areas for selected wetlands investigated for this study

3. Physical properties and concentrations of selected constituents in water samples from selected wetlands, November 2013.

4. Areas for wetland parcels and selected wetland or water features, for wetlands investigated for this study. 


\section{Conversion Factors}

Inch/Pound to International System of Units

\begin{tabular}{|c|c|c|}
\hline Multiply & By & To obtain \\
\hline \multicolumn{3}{|c|}{ Length } \\
\hline inch (in.) & 2.54 & centimeter $(\mathrm{cm})$ \\
\hline inch (in.) & 25.4 & millimeter (mm) \\
\hline foot $(\mathrm{ft})$ & 0.3048 & meter $(\mathrm{m})$ \\
\hline mile (mi) & 1.609 & kilometer $(\mathrm{km})$ \\
\hline \multicolumn{3}{|c|}{ Area } \\
\hline acre & 4,047 & square meter $\left(\mathrm{m}^{2}\right)$ \\
\hline square mile $\left(\mathrm{mi}^{2}\right)$ & 2.590 & square kilometer $\left(\mathrm{km}^{2}\right)$ \\
\hline
\end{tabular}

International System of Units to Inch/Pound

\begin{tabular}{lcl}
\hline \multicolumn{1}{c}{ Multiply } & By & To obtain \\
\hline millimeter $(\mathrm{mm})$ & Length & \\
centimeter $(\mathrm{cm})$ & 0.03937 & inch (in.) \\
meter $(\mathrm{m})$ & 0.3937 & inch (in.) \\
\hline & 3.281 & foot (ft) \\
\hline liter $(\mathrm{L})$ & Volume & gallon (gal) \\
\hline
\end{tabular}

Temperature in degrees Celsius $\left({ }^{\circ} \mathrm{C}\right)$ may be converted to degrees Fahrenheit $\left({ }^{\circ} \mathrm{F}\right)$ as follows:

${ }^{\circ} \mathrm{F}=\left(1.8 x^{\circ} \mathrm{C}\right)+32$

\section{Datum}

Vertical coordinate information is referenced to the North American Vertical Datum of 1988 (NAVD 88) computed using Geoid12 from NAD 83 (2011, epoch 2010.00).

Horizontal coordinate information is referenced to the North American Datum of 1983 (NAD 83, 2011, epoch 2010.00).

Altitude, as used in this report, refers to distance above the vertical datum.

\section{Supplemental Information}

Specific conductance is given in microsiemens per centimeter at 25 degrees Celsius $(\mu \mathrm{S} / \mathrm{cm}$ at $\left.25^{\circ} \mathrm{C}\right)$.

Concentrations of chemical constituents in water are given either in milligrams per liter (mg/L) or micrograms per liter $(\mu \mathrm{g} / \mathrm{L})$. 


\title{
Abbreviations
}

\author{
ATV all-terrain vehicle \\ GIS geographic information system \\ GNSS global navigation satellite system \\ LBST Lower Brule Sioux Tribe \\ NWI National Wetlands Inventory \\ NWOL National Water Quality Laboratory \\ OPUS Online Positioning User Service \\ RTK real-time kinematic \\ USGS U.S. Geological Survey
}





\title{
Ground-Survey and Water-Quality Data for Selected Wetlands on or near the Lower Brule Indian Reservation in South Dakota, 2012-13
}

\author{
By Kathleen M. Neitzert and Ryan F. Thompson
}

\section{Abstract}

Numerous lakes, ponds, and wetlands are located within the Lower Brule Indian Reservation. Wetlands are an important resource providing aquatic habitat for plants and animals, and acting as a natural water filtration system. Several of the wetlands on or near the reservation are of particular interest, but information on the physical and biological integrity of these wetlands was needed to provide a base-line reference when planning for future water management needs. A reconnaissance-level study of selected wetlands on and near the Lower Brule Indian Reservation was completed in 2012-13 by the U.S. Geological Survey in cooperation with the Lower Brule Sioux Tribe using ground surveys and water-quality analyses. Ground surveys of six wetland areas (Dorman Slough, Little Bend Wetlands, Miller Pond, Potter Slough, an unnamed slough, and West Brule Community wetlands) were completed to map land, water, vegetation, and man-made features of the selected wetland areas using real-time kinematic global navigation satellite systems equipment. Water samples were collected from four of the selected wetlands. Two separate waterbodies were sampled at one of the wetlands for a total of five sampling locations. Water samples were analyzed for physical properties, selected inorganics, metals, nutrients, and suspended sediment. Concentrations of calcium, sodium, and sulfate were greater at the two wetland sites fed by ground water, compared to the wetland sites fed by surface runoff.

\section{Introduction}

The Lower Brule Indian Reservation (fig. 1) borders the Missouri River in central South Dakota and is home to the Lower Brule Sioux Tribe (LBST). The land is generally rolling hills, with scenic river bluffs. Agriculture, farming, and ranching are important in the history and current (2015) way of life on the reservation. Abundant wildlife is found on the reservation, and the Missouri River is an important recreational area and migration corridor for waterfowl and other birds.
The Lower Brule Indian Reservation covers an area of about 404 square miles $\left(\mathrm{mi}^{2}\right)$ southwest of the Missouri River in central South Dakota. Most of the reservation is within Lyman County, and a small area is located in southeastern Stanley County. Big Bend Dam impounds Lake Sharpe, which forms most of the northeastern boundary of the reservation. Downstream from Lake Sharpe is Lake Francis Case, which is impounded by Fort Randall Dam (not shown, about 100 miles [mi] to the southeast). Water resources of the Lower Brule Indian Reservation were described by Ogle (1995). Numerous lakes, ponds, and wetlands are located within the reservation. All streams on the reservation other than the Missouri River are ephemeral. Groundwater supplies from surficial deposits are limited and commonly of relatively poor quality. Agriculture, primarily livestock and crop production, is the major industry (South Dakota Agricultural Statistics Service, 2012).

Wetlands are an important resource on the Lower Brule Indian Reservation. Some of the wetlands found on the reservation are created and sustained by flowing wells. Wetlands are important for agriculture and wildlife, providing aquatic habitat for plants and animals, and acting as a natural water filtration system. Wetlands are characterized as a body of water with a water table at or near the land surface that is able to support aquatic plants. Wetlands typically support many species of migratory and resident birds, reptiles, and amphibians (Rieger and others, 2006). Several of the wetlands on or near the reservation are of particular interest to the LBST for a variety of reasons, including their location near tribal communities or historically significant cultural sites and recreational use by hunters and fishermen. Information on the physical and biological integrity of wetlands on and near the reservation was needed by the LBST to provide a base-line reference when planning for future water management needs.

To address this information need, a reconnaissance-level study of six selected wetland areas on and near the Lower Brule Indian Reservation was completed in $2012-13$ by the U.S. Geological Survey (USGS) in cooperation with the LBST using ground surveys and water-quality analyses. Ground surveys were completed to map land, water, vegetation, and manmade features of the selected wetland areas. Water-quality 

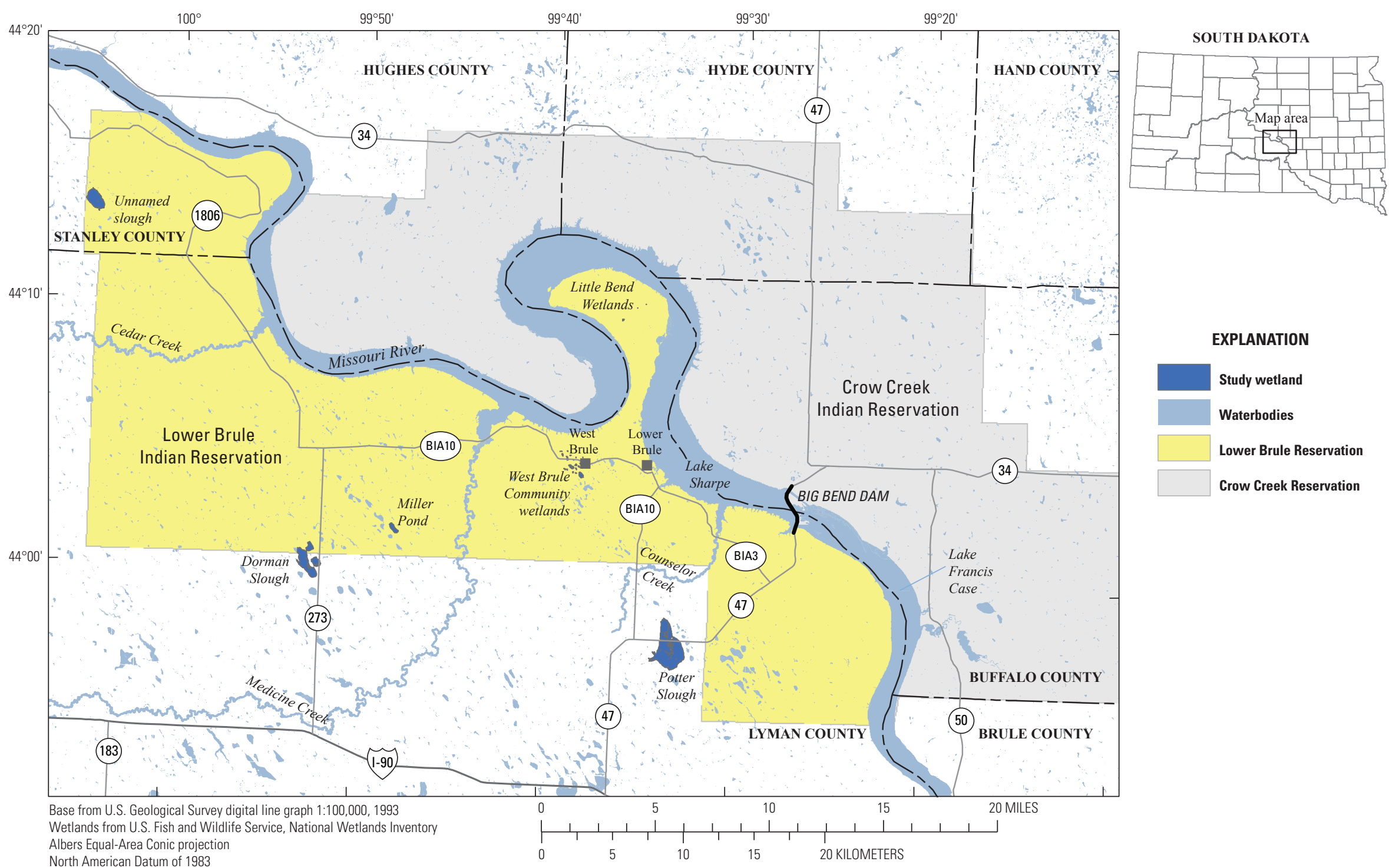

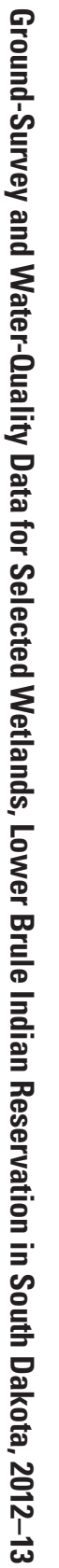

Figure 1. Location of the Lower Brule Indian Reservation in South Dakota and generalized location of selected wetlands investigated for this study. 
samples were collected from wetlands with sufficient water for sample collection.

\section{Purpose and Scope}

The purpose of this report is to present ground-survey and water-quality data collected during a reconnaissancelevel study of the six selected wetland areas on or near the Lower Brule Indian Reservation during 2012-13. Data from the ground surveys include various land, water, and vegetation features for the six wetland areas. Water-quality data are presented for samples collected from four of the selected wetlands. Two separate waterbodies were sampled at one of the wetlands for a total of five sampling locations. Water-quality data include physical properties, selected inorganics, metals, nutrients, and suspended sediment.

\section{Previous Investigations}

The National Wetlands Inventory (NWI; U.S. Fish and Wildlife Service, 2014a) provided initial information regarding wetland locations and classifications. Although little other information exists regarding physical or water-quality conditions for wetlands on the Lower Brule Indian Reservation, several previous investigations provided useful background information for completing the surveys described in this report. La Rocque (1966) evaluated the general availability and depth to groundwater in the Missouri River Basin. Howells (1974) investigated the geohydrology of the Lower Brule and Crow Creek Indian Reservations and evaluated surface-water resources, surficial geology, shallow groundwater resources, geohydrology of the bedrock aquifers, and selected water-quality conditions. These reports provide useful background information regarding groundwater conditions in the vicinity of wetlands.

Francis-Meador-Gellhaus, Inc., Consulting Engineers $(1978,1980)$ conducted a two-phase study of the quantity and quality of water resources within the Lower Brule Indian Reservation. The first report, "Phase I" (Francis-Meador-Gellhaus, Inc., Consulting Engineers, 1978), described the general physiography of the reservation, water-rights issues, major drainage basins, climate, relations between surface-water and groundwater, water quality, potential future sources of water, and the establishment of a hydrologic monitoring network. The second report, "Phase II" (Francis-Meador-Gellhaus, Inc. Consulting Engineers, 1980), described tribal goals and objectives; economic base and projections for the reservation; land and agricultural resources; fish and wildlife resources; recreation and tourism; municipal, rural, and industrial water needs; energy aspects; watershed management; and pollution control and water quality.
A water-resources appraisal of the Lower Brule Indian Reservation was completed by Ogle (1995). That report presented a compilation and analysis of hydrologic data; an inventory of surface-water resources using 1991 aerial photographs; an inventory of water wells; a literature review that included Indian water-rights issues; and a compilation and analysis of water-use data.

\section{Wetlands Classification and Site Selection}

Through the NWI, the U.S. Fish and Wildlife Service (2014a) has classified national wetlands using assigned inventory codes developed to correspond to the classification nomenclature that best describes various wetland conditions. In some cases, wetlands are assigned multiple codes to note multiple effects on the wetlands. The total area on the Lower Brule Indian Reservation that is classified as wetlands by the NWI (U.S. Fish and Wildlife Service, 2014b) is approximately 5,300 acres (table 1) when including two wetlands (Dorman Slough and Potter Slough) that are partially located on tribal lands outside the reservation boundary (fig. 1). Many wetlands within the reservation are stock dams or dugouts constructed to catch and hold water for livestock watering. Ogle (1995) estimated a total area of about 1,300 acres for 593 stock dams or dugouts within the reservation boundary. Stock dams typically are constructed from small earthen dams located on small stream channels. Dugouts typically are excavations within depressions (commonly within or adjacent to wetland areas), with excavated material typically placed in one or more berms or spoil piles. Dugouts commonly can hold water during periods when the surrounding depressions or wetlands are dry.

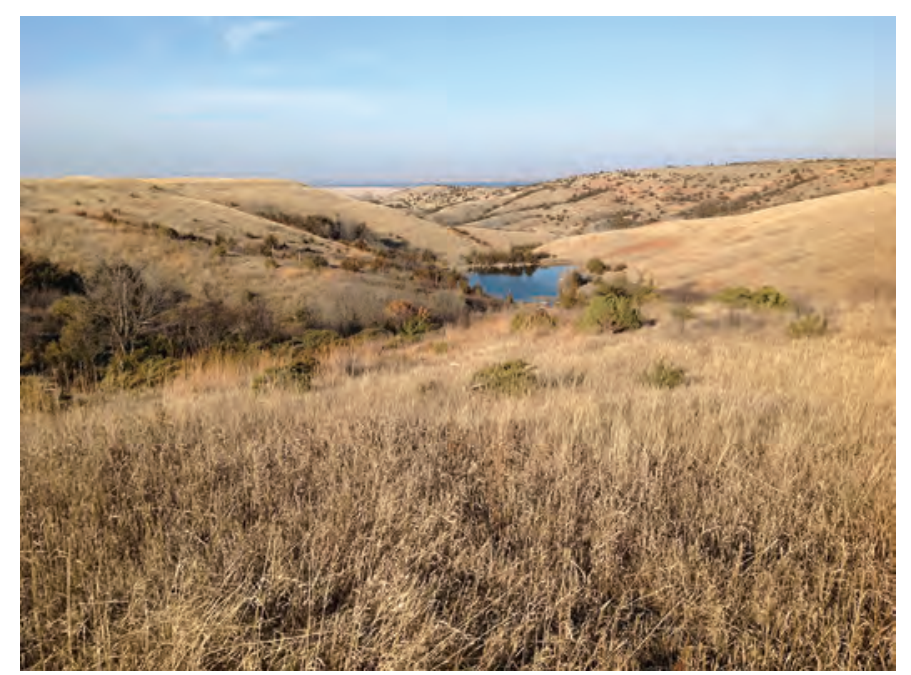

Small stock dam near West Brule Community. 


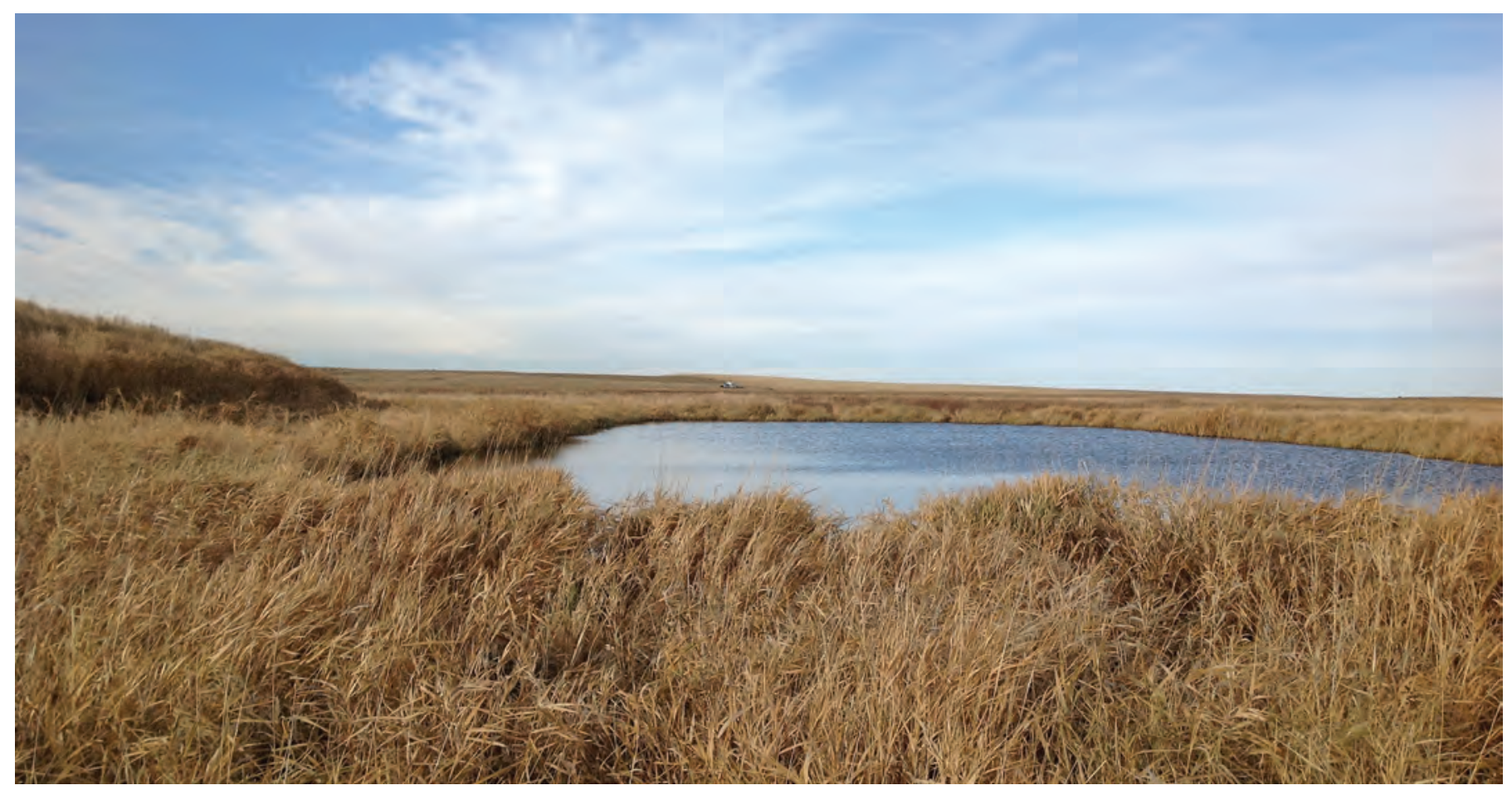

Dugout at unnamed slough.

Table 1. National Wetland Inventory classifications and areas for wetlands located on the Lower Brule Indian Reservation.

\begin{tabular}{|c|c|}
\hline $\begin{array}{l}\text { National Wetlands Inventory } \\
\text { classification type }\end{array}$ & $\begin{array}{c}\text { Total area classified as } \\
\text { wetlands on Lower Brule } \\
\text { Indian Reservation }{ }^{2} \\
\text { (acres) }\end{array}$ \\
\hline Freshwater emergent wetland & 4,050 \\
\hline $\begin{array}{l}\text { Freshwater forested/shrub } \\
\text { wetland }\end{array}$ & 116 \\
\hline Freshwater pond & 1,090 \\
\hline Lake & 48.3 \\
\hline Riverine & 1.24 \\
\hline Other & 2.04 \\
\hline Total & 5,300 \\
\hline
\end{tabular}

${ }^{1}$ U.S. Fish and Wildlife Service (2014b).

${ }^{2}$ Area includes two wetlands (Dorman Slough and Potter Slough; fig. 1) located on land outside of the Lower Brule Indian Reservation where the Lower Brule Sioux Tribe has partial ownership.

Six wetland areas (table 2) were selected for investigation for this study because of particular interest to LBST for various reasons, including locations near tribal communities or historically significant cultural sites and recreational use by hunters and fishermen. Four of the wetland areas are located within the Lower Brule Indian Reservation (fig. 1), and two wetland areas (Dorman Slough and Potter Slough) are located on land outside of the reservation boundary where LBST has partial ownership. The selected wetland areas range in size from about 34 to 1,050 acres and are fairly well distributed throughout the area, with five located in Lyman County, and one in Stanley County. The following wetlands were selected by the LBST for investigation:

- Dorman Slough, located just south of the reservation, but partially owned by LBST;

- Little Bend Wetlands, an area that includes three wetlands constructed by LBST as a food plot for migratory waterfowl and to provide hunting opportunities;

- Miller Pond, a large permanent pond in the southcentral part of the reservation that is managed for recreation;

- Potter Slough, located south of the reservation, but partially owned by LBST;

- an "unnamed slough" in the northwestern part of the reservation; and

- West Brule Community wetlands, which includes many small depressions near West Brule Community.

The Little Bend Wetlands were constructed by the LBST Wildlife Unit staff by building levees or berms on a gently 
Table 2. National Wetland Inventory classifications and areas for selected wetlands investigated for this study.

\begin{tabular}{llc}
\hline Wetland name & \multicolumn{1}{c}{$\begin{array}{c}\text { National Wetlands Inventory' } \\
\text { classification type }\end{array}$} & $\begin{array}{c}\text { Approximate area based on National } \\
\text { Wetland Inventory' (acres) }\end{array}$ \\
\hline Dorman Slough & Freshwater emergent wetland & 466 \\
& Freshwater pond & 6.88 \\
& Other & 1.54 \\
& Total of all classifications & 474 \\
\hline Little Bend Wetlands & Not determined & Not determined \\
Miller Pond & Freshwater emergent wetland & 50.6 \\
& Freshwater pond & 0.49 \\
& Total of all classifications & 51.1 \\
\hline Potter Slough & Freshwater emergent wetland & 1,050 \\
& Freshwater pond & 0.47 \\
& Total of all classifications & 1,050 \\
\hline Unnamed slough & Freshwater emergent wetland & 276 \\
& Total of all classifications & 276 \\
\hline West Brule Community wetlands & Freshwater emergent wetland & 33.9 \\
& Total of all classifications & 33.9 \\
\hline
\end{tabular}

${ }^{1}$ U.S. Fish and Wildlife Service (2014b).

sloping area previously incapable of holding water. These wetlands were constructed after the NWI classification system was developed, so an NWI classification for the Little Bend Wetlands is not listed in table 2 . The primary NWI classification for the other five wetland areas is "freshwater emergent wetland." Three of these five wetlands have secondary NWI classifications of "freshwater pond" because of dugouts located within the wetland areas.

Four of the wetlands are managed primarily for waterfowl production, and LBST has planted food plots, typically sorghum, near each of these wetlands. The exceptions are the West Brule Community wetlands, which are used for multiple municipal and agricultural purposes, and the Little Bend Wetlands. The Little Bend Wetlands typically are planted to corn in the spring, and then flooded in the fall to provide a feeding area for waterfowl and hunting opportunities.

\section{Methods}

This section describes the methods used for the ground surveys, which were performed for all six wetlands (table 2), and for collection and analysis of water samples. Water samples were collected from four of the selected wetlands; however, two separate waterbodies were sampled at one of the wetlands for a total of five sampling locations.

\section{Ground-Survey Methods}

Compilation of existing data began in August 2012 to aid in preliminary determination of wetland locations and to collect basic site information. During an initial reconnaissance visit in August 2012, only two of the six selected wetland areas contained water (Miller Pond and some of the wetlands in the West Brule Community wetlands). Ground surveys of the wetlands were completed during non-ice conditions in 2012 and 2013.

Ground surveys were performed to map land, water, and vegetation features of selected wetlands using real-time kinematic (RTK) surveying methods with global navigation satellite system (GNSS) equipment. The RTK method uses a stationary "base" GNSS receiver, which transmits real-time differential correction signals to one or more mobile "rover" GNSS receivers used to collect data at objective points. The distance between the base and rovers can be as much as several miles in flat terrain, but will be less if the differential correction signal is blocked by hills or other obstructions. For this study, the maximum baseline length was about 4 mi. Data collected at each objective point included latitude and longitude, land-surface elevation, and a descriptive code. The codes were assigned by the surveyor to identify the primary land, water, or vegetation feature at that point (for example, cattail edge, dugout edge, access road, edge of water, or edge of food plot). 
Because of the remote locations of many of the selected wetlands and the sparse bench mark network in the reservation area, established bench marks with published coordinates typically were not available for GNSS RTK base occupations. In the absence of bench marks, other objects presumed to be somewhat permanent and stable (such as a right-of-way monument or a fencepost) were selected for RTK base occupations where available. Where stable and relatively permanent objects could not be located, an attempt was made to set up the GNSS base without establishing a reference mark in a somewhat-prominent, yet central location. This was done in an effort to maximize the range of the differential correction signal while minimizing the baseline length between the base and rover receivers. Static occupation files from all base locations were processed using the Online Positioning User Service (OPUS; National Geodetic Survey, 2014). The coordinates of each objective point were then adjusted based on the OPUS solution for the coordinates of the base. Horizontal accuracy of the GNSS equipment being used in RTK mode is specified by the manufacturer as 0.3937 inch (in.; 10 millimeters [mm]) plus 1 part per million times the baseline length (Topcon Positioning Systems, 2007). The maximum baseline length

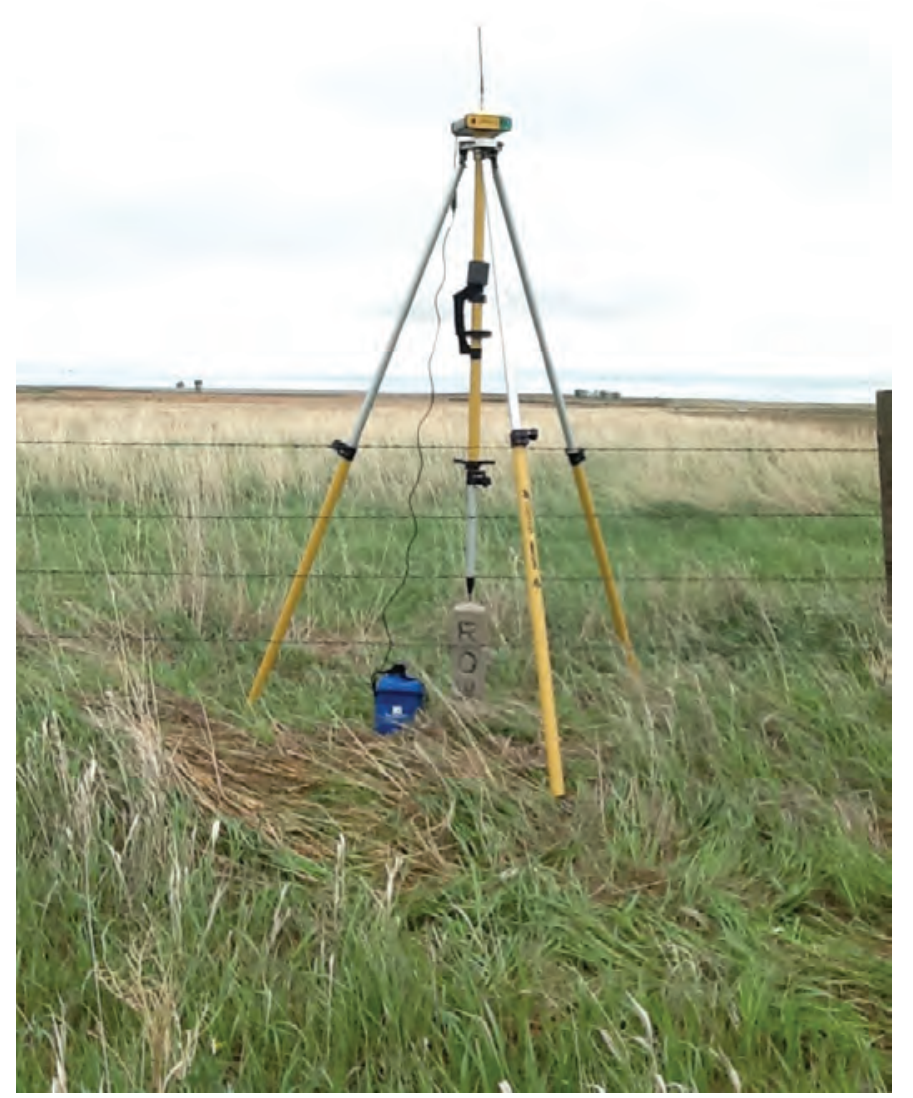

Survey base station near southern part of Potter Slough. varied by wetland and ranged from $0.60 \mathrm{mi}$ at the unnamed slough to about $4.03 \mathrm{mi}$ at Miller Pond. The resulting horizontal error for a 4.03-mi baseline is about 0.65 in. Vertical errors specified by the GNSS manufacturer used in RTK mode are $0.5906 \mathrm{in}$. (15 mm) plus 1 part per million times the baseline length (Topcon Positioning Systems, 2007). The resulting vertical error for a 4.03-mi baseline is about 0.85 in. The GNSS surveying methods used to support this study met or exceeded the quality descriptions for a Level IV GNSS survey (Rydlund and Densmore, 2012).

Although each wetland had some aspects making it unique, some features were common to all of the wetland areas. Cattails were present and mapped at each wetland, or within at least some of the wetlands grouped together because of proximity (wetland complexes). Another feature common to all of the ground surveys was that cross sections were collected within the wetland, at the wetland edge, and in some cases also in the upland areas adjacent to the wetland or between wetlands within a wetland complex. Each crosssection point is useful for comparing elevations between locations. For some wetlands, cross sections also were collected at human-made features (such as roads or fences) that served as a convenient perimeter, within which all of the other groundsurvey information was contained. This perimeter defined the area for each "wetland parcel" that was surveyed and within which was one or more individual wetlands or wetland complexes. Another feature common to all of the ground surveys was the identification of perimeters of standing water bodies within each wetland parcel; however, in some cases dense vegetation or flat terrain made it difficult or impractical to accurately define the edge of water. Some wetland parcels included other human-made features such as water-supply pipes, outlet control structures, and berms. For the purposes of this investigation, a berm is a general term used to describe a pile of soil. Some berms were spoil piles from constructed dugouts, whereas other berms were levees built to hold water in a constructed wetland or a pile of construction fill. In addition to cattails, some of the wetland parcels included other vegetation features, which may be naturally occurring plants or crops cultivated in wildlife food plots.

The ground surveys were performed either by walking/ wading or by using a small all-terrain vehicle (ATV) outfitted with an antenna mount that held the GNSS rover. The spacing of the RTK data points varied and depended on the collection method (walking or ATV), and various conditions encountered. Some features can be more easily mapped with fewer points. For example, fewer data points were needed to map a straight fence line or road compared to an irregularly shaped clump of cattails. Survey points collected by using an ATV used an automatic collection method triggered by distance interval. This means that any time the antenna moved a specified distance from the previous point (typically 1 to 3 feet [ft] for this study), a new point was collected. 
Some ground surveys of wetlands were completed in 1 day, whereas others required multiple visits. Two wetlands, Dorman Slough and Potter Slough, were visited four times (once in each season) because of their size and varied vegetation.

Information collected during the ground survey for each wetland was compiled using geographic information system (GIS) software, which allowed for convenient mapping of the georeferenced land features and also allowed for interfacing with other available data, such as mapped NWI data. The GIS datasets for all of the surveyed wetlands are provided in the format of geodatabase feature classes in the appendix of this report.

\section{Water-Quality Methods}

Water samples were collected and analyzed for physical properties, selected inorganics, metals, nutrients (total phosphorus and total nitrogen), and suspended sediment. Water-quality samples were collected following the bulk of fall rains, in November 2013. Five locations at four of the selected wetlands (table 3) were sampled: Dorman Slough, Miller Pond, Potter Slough (north and south locations), and the south wetland of Little Bend Wetlands (South Little Bend Wetland). The unnamed slough was not sampled because of flooding conditions, and the West Brule Community wetlands were not sampled because of insufficient water in the wetlands of interest.

Several of the wetlands had dugouts, and the water-quality samples typically were collected at those dugouts. Dorman Slough includes one dugout (fig. 2) that contained water at the time of sample collection. The South Little Bend Wetland is within the Little Bend wetland complex, which has two separate wetland areas. The larger southern area consists of two adjacent wetlands that are separated by a berm, but connected with pipes and control structures. The sample was collected at the northern edge of the eastern-most of the two southern wetlands (fig. 3), near the flowing well that supplies all three Little Bend Wetlands. Shortly before sampling, the Little Bend Wetlands area had been flooded by the supply well, resulting in much flooded vegetation around the area. The Miller Pond dugout was inundated, and the water-quality sample for this location was collected at the west-central side of the wetland (fig. 4). Potter Slough includes two dugouts; samples were collected from both (north and south) dugouts (fig. 5), and a replicate sample for quality-assurance /quality-control purposes also was collected from the north dugout.

\section{Sample Collection and Analysis}

Sampling procedures followed "clean-sampling" guidelines described by U.S. Geological Survey (2006), but these procedures were adapted to the conditions encountered at the different sites. At each sampling location, sampling procedures generally involved collecting several liters of water by grab sample in a churn splitter and later transferring the water to other appropriate bottles by use of a peristaltic pump in a mobile laboratory. Samples were collected by wading. The suspended-sediment samples were collected based on a modification of the methods described by Edwards and Glysson (1999) for small, low-velocity streams. This involved submerging an open-mouth bottle into the water by hand, with the opening oriented upward at a 45-degree angle near the depth centroid.

Physical properties of barometric pressure, $\mathrm{pH}$, specific conductance, water temperature, and turbidity were measured in place at a depth of approximately 1 foot. Samples collected for laboratory analyses were chilled according to sample specifications and then packed for overnight shipping for analysis at the USGS National Water Quality Laboratory (NWQL) located in Denver, Colorado, or, in the case of nutrients, the samples were sent to a NWQL contract laboratory, RTI Laboratories, Inc., in Livonia, Michigan. Samples for analysis of suspended sediment were shipped to the USGS Iowa Sediment Laboratory in Iowa City, Iowa.

Samples for selected inorganic constituents and metals were analyzed at the NWQL using methods described by Fishman and Friedman (1989). The nutrient samples were analyzed by RTI Laboratories, Inc., for total phosphorus and total nitrogen using method 507 of the U.S. Environmental Protection Agency (1989). Suspended-sediment samples were analyzed for both particle size characterization and concentration, according to standard methodology for USGS sedimentlaboratory operations described by Guy (1969).

\section{Quality Assurance and Quality Control}

Analytical results are intended to describe the environmental conditions at the time of sample collection; however, various factors or circumstances associated with collection, handling, processing or analysis of samples can potentially lead to sample results that are not representative of environmental conditions. Several techniques, collectively known as quality assurance and quality control, are used to identify, quantify, and document bias and variability in data that result from the collection, processing, shipping, and handling of samples (U.S. Geological Survey, 2006). Two qualityassurance samples were collected or processed for this study. The equipment blank sample (processed in the office before the trip) had no detections of any constituents. The replicate sample was collected at the Potter Slough (north dugout). Concentrations of dissolved silica and dissolved iron were much larger in the replicate sample than in the environmental sample (table 3), indicating substantial uncertainty in sample results for these constituents. Concentrations for all other constituents were similar between the environmental and replicate samples. 
Table 3. Physical properties and concentrations of selected constituents in water samples from selected wetlands, November 2013.

[Shaded row indicates a replicate sample collected for quality-assurances purposes. Five-digit numbers in parentheses are U.S. Geological Survey parameter codes. USGS, U.S. Geological Survey; mm, millimeters; $\mathrm{Hg}$, mercury; $\mu \mathrm{S} / \mathrm{cm}$, microsiemens per centimeter at 25 degrees Celsius; ${ }^{\circ} \mathrm{C}$, degrees Celsius; NTRU, nephelometric turbidity unit; $\mathrm{mg} / \mathrm{L}$, milligrams per liter; $\mu \mathrm{g} / \mathrm{L}$, micrograms per liter; $\mathrm{P}$, phosphate; TKN, total Kjeldahl nitrogen; N, nitrogen; S. Dak., South Dakota; E, estimated; <, less than]

\begin{tabular}{|c|c|c|c|c|c|c|c|c|c|c|}
\hline \multirow[t]{2}{*}{ Wetland name } & \multirow[t]{2}{*}{$\begin{array}{l}\text { USGS station iden- } \\
\text { tification number }\end{array}$} & \multirow[t]{2}{*}{$\begin{array}{c}\text { Date } \\
\text { (mm/dd/yyyy) }\end{array}$} & \multirow[t]{2}{*}{ Time } & \multirow[t]{2}{*}{ Sample type } & \multirow{2}{*}{$\begin{array}{c}\begin{array}{c}\text { Barometric } \\
\text { pressure } \\
\text { (mm of } \mathrm{Hg})\end{array} \\
(00025)\end{array}$} & \multirow{2}{*}{$\begin{array}{c}\begin{array}{c}\text { pH,whole } \\
\text { field, stan- } \\
\text { dard units }\end{array} \\
(00400)\end{array}$} & \multirow{2}{*}{$\begin{array}{c}\begin{array}{c}\text { Specific } \\
\text { conductance, } \\
\text { laboratory } \\
(\mu \mathrm{S} / \mathrm{cm})\end{array} \\
(90095)\end{array}$} & \multirow{2}{*}{$\begin{array}{c}\begin{array}{c}\text { Temperature, } \\
\text { water } \\
\left({ }^{\circ} \mathrm{C}\right)\end{array} \\
(00010)\end{array}$} & \multirow{2}{*}{$\begin{array}{l}\begin{array}{c}\text { Turbidity } \\
\text { (NTRU) }\end{array} \\
\text { (63676) }\end{array}$} & \multirow{2}{*}{$\begin{array}{c}\begin{array}{c}\text { Calcium, } \\
\text { dissolved } \\
(\mathrm{mg} / \mathrm{L})\end{array} \\
(00915)\end{array}$} \\
\hline & & & & & & & & & & \\
\hline $\begin{array}{l}\text { Dorman Slough near Kennebec, } \\
\text { S. Dak. }\end{array}$ & 435752099522200 & $11 / 14 / 2013$ & 0820 & Environmental & 711 & 8.2 & 426 & 3.6 & 120 & 25.1 \\
\hline $\begin{array}{l}\text { Little Bend Wetland (south) } \\
\text { near Lower Brule, S. Dak. }\end{array}$ & 440931099341800 & $11 / 13 / 2013$ & 1405 & Environmental & 722 & 8.4 & 2,520 & 4.3 & 38 & 384 \\
\hline $\begin{array}{l}\text { Miller Pond near Kennebec, S. } \\
\text { Dak. }\end{array}$ & 440137099480200 & $11 / 14 / 2013$ & 0930 & Environmental & 712 & 7.7 & 3,730 & 4.8 & E3.0 & 552 \\
\hline $\begin{array}{l}\text { Potter Slough (north) near } \\
\text { Lower Brule, S. Dak. }\end{array}$ & 435759099333000 & $11 / 13 / 2013$ & 1055 & Environmental & 712 & 7.3 & 140 & 3.0 & 110 & 10.1 \\
\hline $\begin{array}{l}\text { Potter Slough (north) near } \\
\text { Lower Brule, S. Dak. }\end{array}$ & 435759099333000 & $11 / 13 / 2013$ & 1056 & Replicate & 715 & 7.3 & 140 & 3.0 & 120 & 11.4 \\
\hline $\begin{array}{l}\text { Potter Slough (south) near } \\
\text { Lower Brule, S. Dak. }\end{array}$ & 435723099332700 & $11 / 13 / 2013$ & 0945 & Environmental & 715 & 8.5 & 398 & 2.9 & 33 & 34.6 \\
\hline \multirow[t]{2}{*}{ Wetland name } & \multirow[t]{2}{*}{$\begin{array}{l}\text { USGS station iden- } \\
\text { tification number }\end{array}$} & \multirow[t]{2}{*}{$\begin{array}{c}\text { Date } \\
\text { (mm/dd/yyyy) }\end{array}$} & \multirow[t]{2}{*}{ Time } & \multirow[t]{2}{*}{ Sample type } & $\begin{array}{c}\text { Silica, } \\
\text { dissolved } \\
\text { (mg/L) }\end{array}$ & $\begin{array}{c}\text { Sodium, } \\
\text { dissolved } \\
\text { (mg/L) }\end{array}$ & $\begin{array}{c}\text { Sulfate, } \\
\text { dissolved } \\
\text { (mg/L) }\end{array}$ & $\begin{array}{c}\text { Iron, } \\
\text { dissolved } \\
(\mu \mathrm{g} / \mathrm{L})\end{array}$ & $\begin{array}{c}\text { Lead, } \\
\text { dissolved } \\
(\mu \mathrm{g} / \mathrm{L})\end{array}$ & $\begin{array}{c}\text { Selenium, } \\
\text { dissolved } \\
(\mu \mathrm{g} / \mathrm{L})\end{array}$ \\
\hline & & & & & (00955) & (00930) & $(00945)$ & (01046) & (01049) & (01147) \\
\hline $\begin{array}{l}\text { Dorman Slough near Kennebec, } \\
\text { S. Dak. }\end{array}$ & 435752099522200 & $11 / 14 / 2013$ & 0820 & Environmental & 2.85 & 63.5 & 4.96 & 240 & 0.123 & 0.679 \\
\hline $\begin{array}{l}\text { Little Bend Wetland (south) } \\
\text { near Lower Brule, S. Dak. }\end{array}$ & 440931099341800 & $11 / 13 / 2013$ & 1405 & Environmental & 5.59 & 137 & 1,300 & 8.0 & $<0.080$ & 0.224 \\
\hline $\begin{array}{l}\text { Miller Pond near Kennebec, S. } \\
\text { Dak. }\end{array}$ & 440137099480200 & $11 / 14 / 2013$ & 0930 & Environmental & 1.83 & 193 & 1,790 & 34.6 & $<0.120$ & 0.212 \\
\hline $\begin{array}{l}\text { Potter Slough (north) near } \\
\text { Lower Brule, S. Dak. }\end{array}$ & 435759099333000 & $11 / 13 / 2013$ & 1055 & Environmental & 28.3 & 15.6 & 13.6 & 2,100 & 0.364 & 0.593 \\
\hline $\begin{array}{l}\text { Potter Slough (north) near } \\
\text { Lower Brule, S. Dak. }\end{array}$ & 435759099333000 & $11 / 13 / 2013$ & 1056 & Replicate & 41.8 & 15.7 & 13.7 & 4,380 & 1.06 & 0.541 \\
\hline $\begin{array}{l}\text { Potter Slough (south) near } \\
\text { Lower Brule, S. Dak. }\end{array}$ & 435723099332700 & $11 / 13 / 2013$ & 0945 & Environmental & 19.5 & 46.3 & 15.0 & 212 & 0.076 & 0.540 \\
\hline
\end{tabular}


Table 3. Physical properties and concentrations of selected constituents in water samples from selected wetlands, November 2013.-Continued

[Shaded row indicates a replicate sample collected for quality-assurances purposes. Five-digit numbers in parentheses are U.S. Geological Survey parameter codes. USGS, U.S. Geological Survey; mm, millimeters; $\mathrm{Hg}$, mercury; $\mu \mathrm{S} / \mathrm{cm}$, microsiemens per centimeter at 25 degrees Celsius; ${ }^{\circ} \mathrm{C}$, degrees Celsius; NTRU, nephelometric turbidity unit; mg/L, milligrams per liter; $\mu \mathrm{g} / \mathrm{L}$, micrograms per liter; $\mathrm{P}$, phosphate; TKN, total Kjeldahl nitrogen; N, nitrogen; S. Dak., South Dakota; E, estimated; <, less than]

\begin{tabular}{|c|c|c|c|c|c|c|c|c|c|}
\hline Wetland name & $\begin{array}{c}\text { USGS station } \\
\text { identification } \\
\text { number }\end{array}$ & $\begin{array}{c}\text { Date } \\
\text { (mm/dd/yyyy) }\end{array}$ & Time & Sample type & $\begin{array}{c}\text { Phosphorus, } \\
\text { total } \\
\text { (mg/L as } \mathrm{P} \text { ) }\end{array}$ & $\begin{array}{c}\text { Nitrogen, } \\
\text { ammonia } \\
\text { (mg/L as } \\
\text { TKN) }\end{array}$ & $\begin{array}{c}\text { Nitrogen, nitrate } \\
\text { plus nitrite } \\
\text { (mg/L as N) }\end{array}$ & $\begin{array}{l}\text { Suspended } \\
\text { sediment finer } \\
\text { than diameter } \\
\mathbf{0 . 0 6 2} \mathbf{~ m m} \\
\text { (percent) }\end{array}$ & $\begin{array}{c}\text { Suspended } \\
\text { sediment } \\
\text { (mg/L) }\end{array}$ \\
\hline & & & & & (01413) & (00625) & (00630) & (70331) & (80154) \\
\hline $\begin{array}{l}\text { Dorman Slough near Kennebec, } \\
\text { S. Dak. }\end{array}$ & 435752099522200 & $11 / 14 / 2013$ & 0820 & Environmental & 0.24 & 1.2 & $<0.019$ & 98 & 115 \\
\hline $\begin{array}{l}\text { Little Bend Wetland (south) near } \\
\text { Lower Brule, S. Dak. }\end{array}$ & 440931099341800 & $11 / 13 / 2013$ & 1405 & Environmental & 0.17 & 1.3 & $<0.019$ & 85 & 96 \\
\hline $\begin{array}{l}\text { Miller Pond near Kennebec, S. } \\
\text { Dak. }\end{array}$ & 440137099480200 & $11 / 14 / 2013$ & 0930 & Environmental & 0.40 & 1.8 & 0.190 & 65 & 15 \\
\hline $\begin{array}{l}\text { Potter Slough (north) near Lower } \\
\text { Brule, S. Dak. }\end{array}$ & 435759099333000 & $11 / 13 / 2013$ & 1055 & Environmental & 0.50 & 1.6 & E0.091 & 96 & 125 \\
\hline $\begin{array}{l}\text { Potter Slough (north) near Lower } \\
\text { Brule, S. Dak. }\end{array}$ & 435759099333000 & $11 / 13 / 2013$ & 1056 & Replicate & 0.52 & 1.7 & E0.091 & 97 & 122 \\
\hline $\begin{array}{l}\text { Potter Slough (south) near Lower } \\
\text { Brule, S. Dak. }\end{array}$ & 435723099332700 & $11 / 13 / 2013$ & 0945 & Environmental & 0.37 & 1.7 & $<0.019$ & 93 & 58 \\
\hline
\end{tabular}




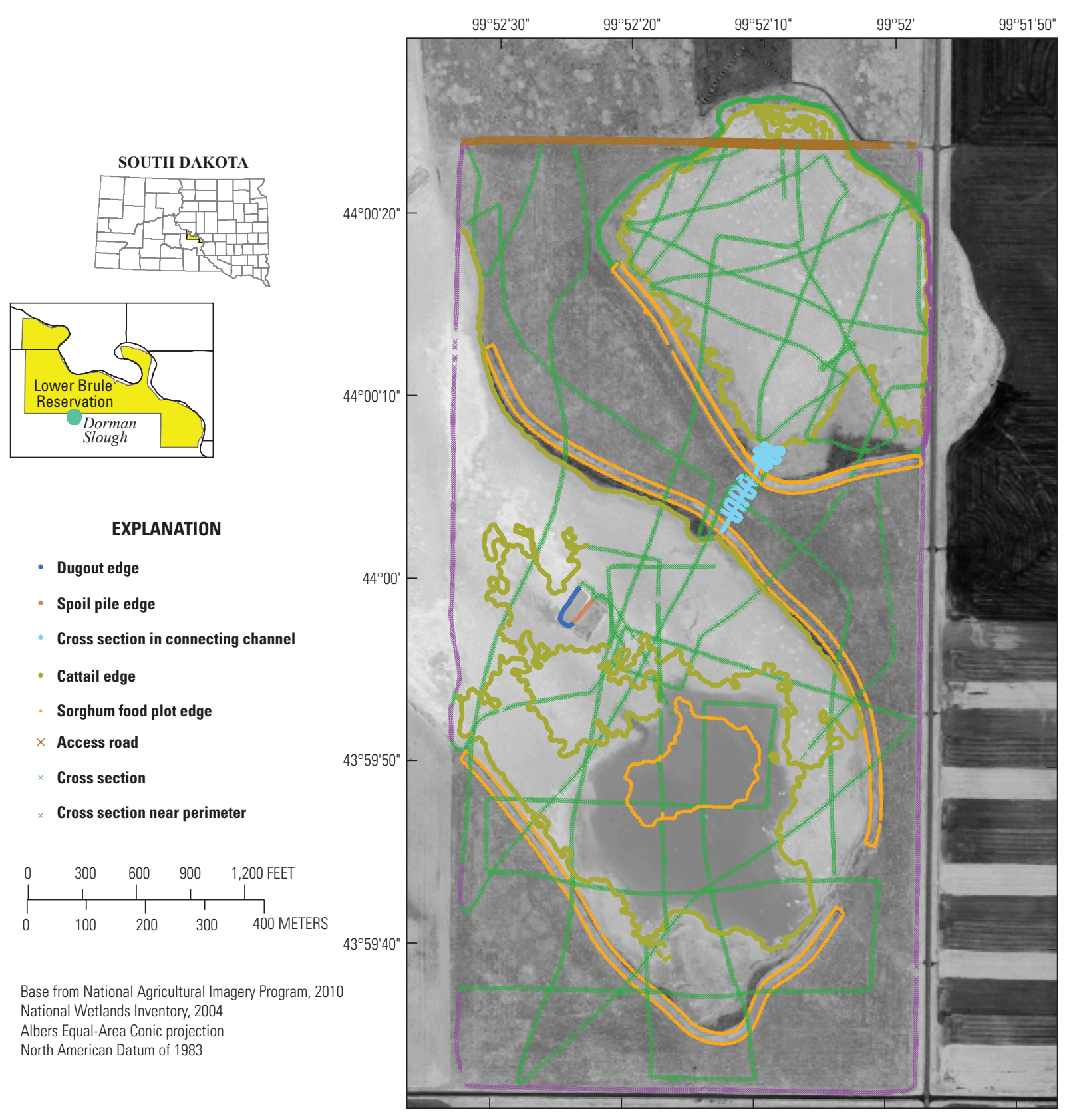

Full extent of Dorman Slough wetland complex

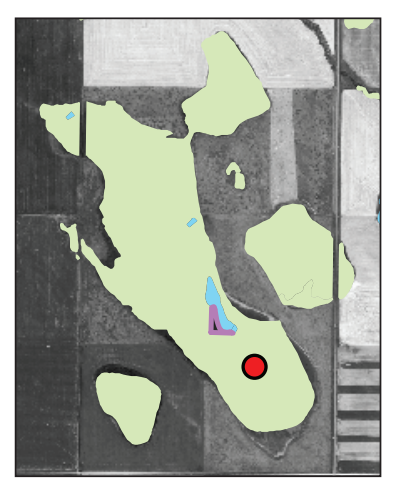

Figure 2. Primary land, water, and vegetation features for the Dorman Slough wetland parcel. 


\section{EXPLANATION}

○ Water-supply pump

- Water-supply pipe

(2) Water-supply outlet

(†) Outlet control structure

- Control structure pipe

- Pit hunting blind

$\times$ Access road

- Berm (top)

- Berm base (inside)

- Berm base (outside)

+ Ditch

- Fence post

- Cattail edge

- Grass edge

- Edge of planted area Natural drainage path

- Old high water mark Cross section

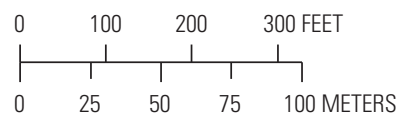

Base from National Agricultural Imagery Program, 2010 National Wetlands Inventory, 2004 Albers Equal-Area Conic projection Albers Equal-Area Conic projection
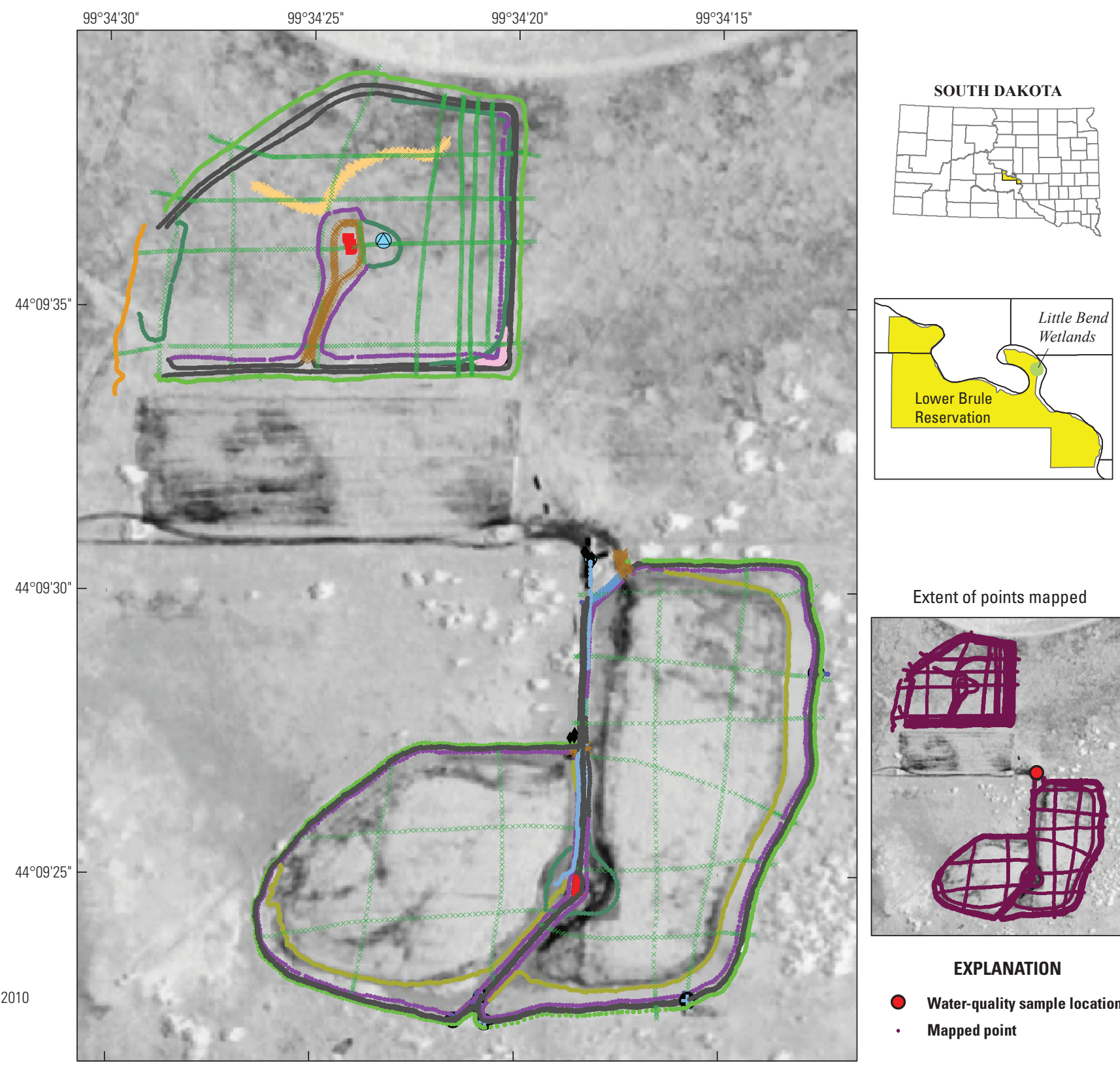

Extent of points mapped

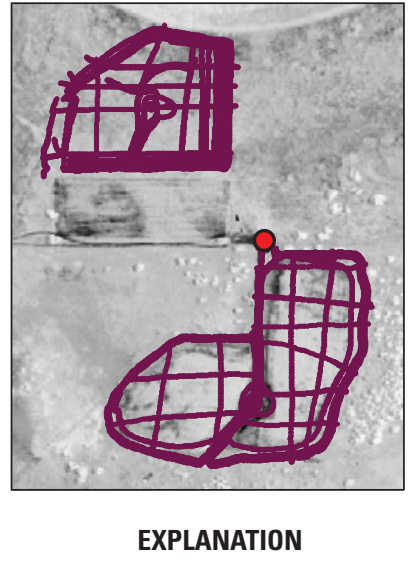

○ Water-quality sample location Mapped point

Figure 3. Primary land, water, and vegetation features for the Little Bend Wetlands parcel. 


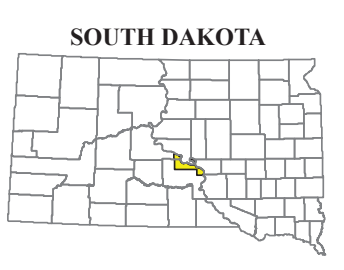

Extent of Miller Pond Wetland Complex

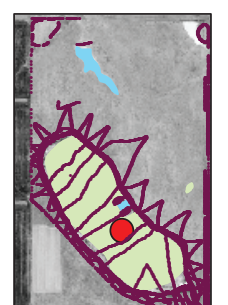

EXPLANATION

\section{Freshwater pond}

Freshwater emergent wetland

Water-quality sample location

Mapped point

Extent of points mapped
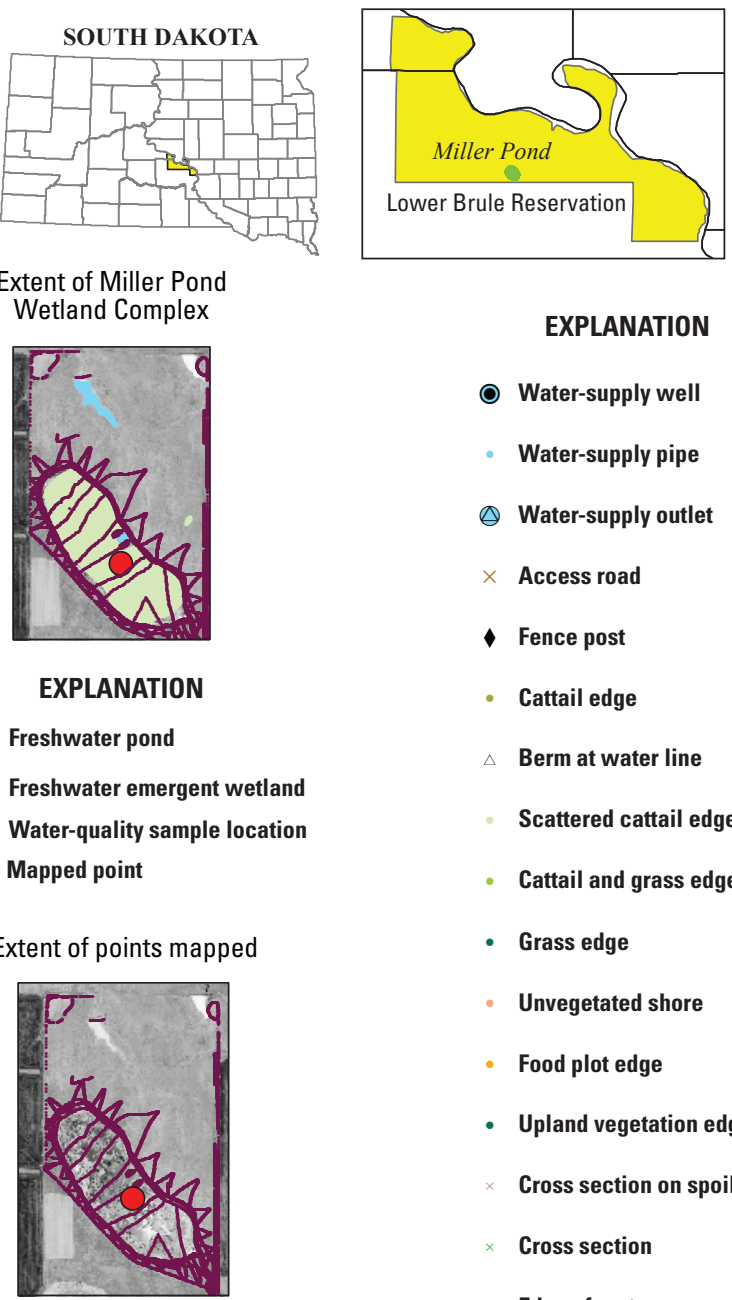

EXPLANATION

○ Water-supply well

Water-supply pipe

(ब) Water-supply outlet

$\times$ Access road

- Fence post

- Cattail edge

Berm at water line

Scattered cattail edge

Cattail and grass edge

- Grass edge

- Unvegetated shore

Food plot edge

- Upland vegetation edge

Cross section on spoil pile

Cross section

- Edge of water

- Fenceline $99^{\circ} 48^{\prime} 20^{\prime \prime}$

$99^{\circ} 48^{\prime} 10^{\prime \prime}$

$99^{\circ} 48$

$99^{\circ} 47^{\prime} 50^{\prime \prime}$

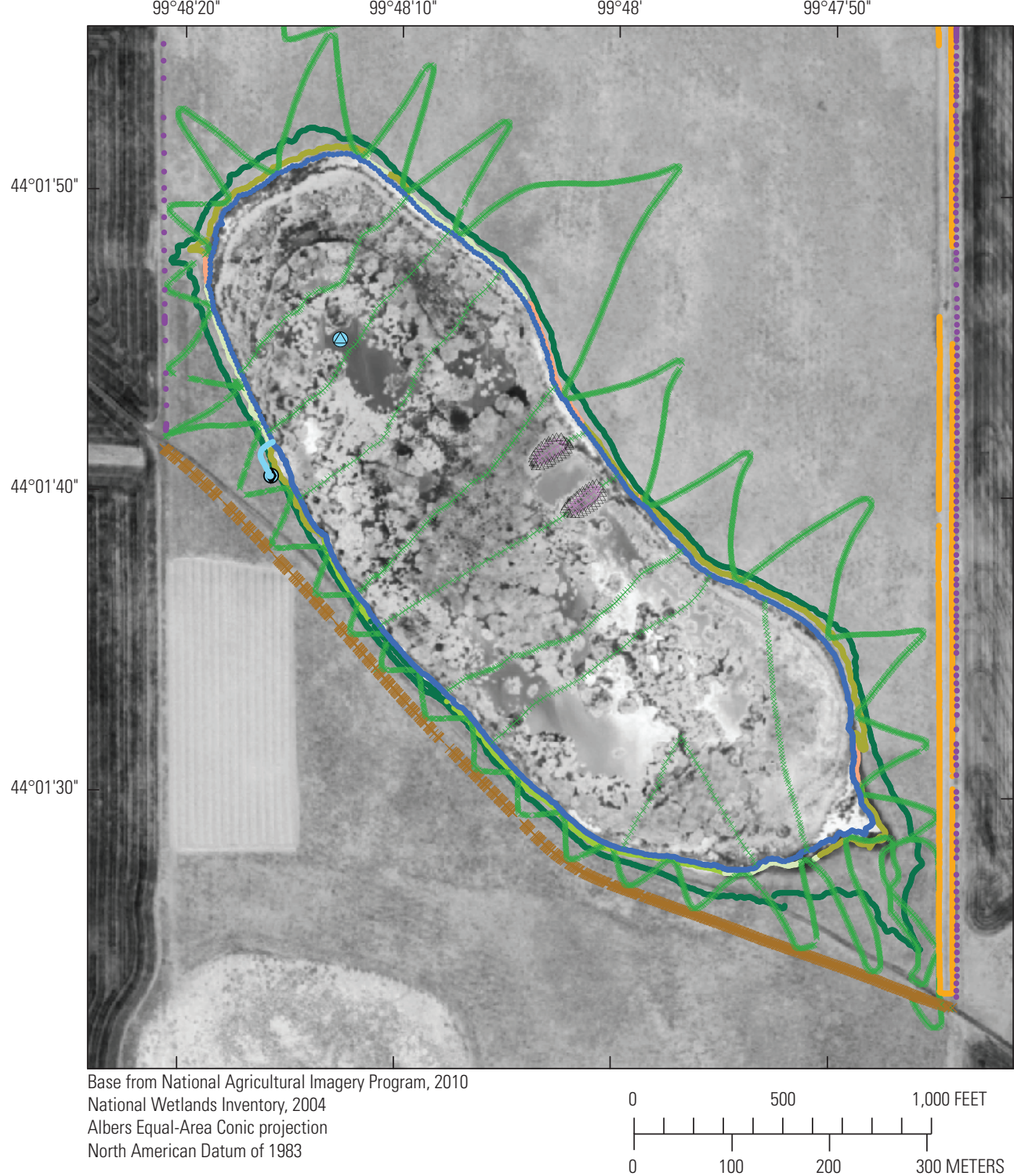

Figure 4. Primary land, water, and vegetation features for the Miller Pond wetland parcel. 

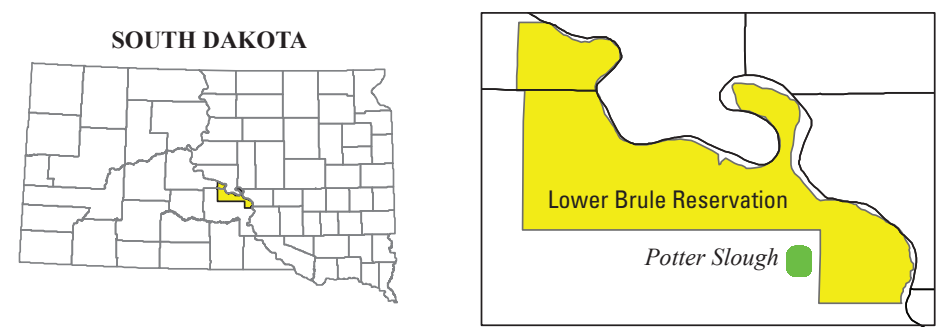

Extent of points mapped

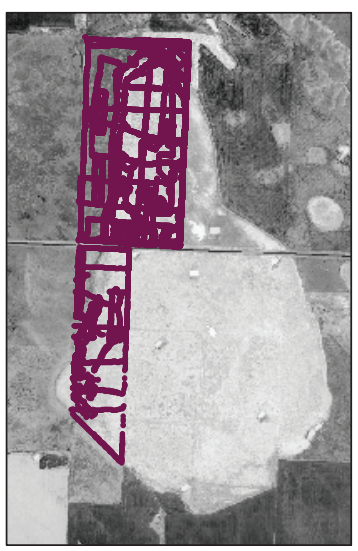

Full Extent of Potter Slough

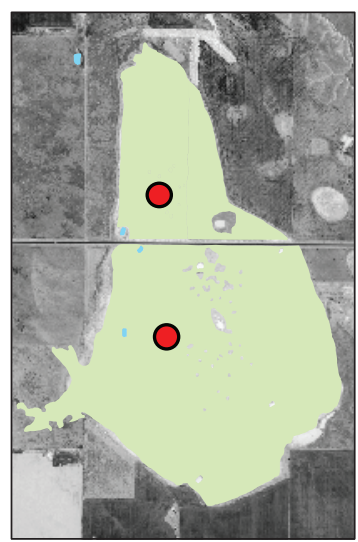

EXPLANATION

Freshwater pond

Freshwater emergent wetland

Water-quality sample location

\section{EXPLANATION}

$\otimes$ Culvert

Cross section

Cross section, near perimeter

Cross section on spoil pile

- Cattail and grass edge

- Fenceline

Natural drainage path

- Cattail edge

$\triangle$ Curly dock edge

- Parking area edge

- Dugout edge

- Unvegetated ground, edge

- Food plot edge

$\triangle$ Tree

$\triangle$ Tree cluster edge

$\triangle$ Water plantain edge

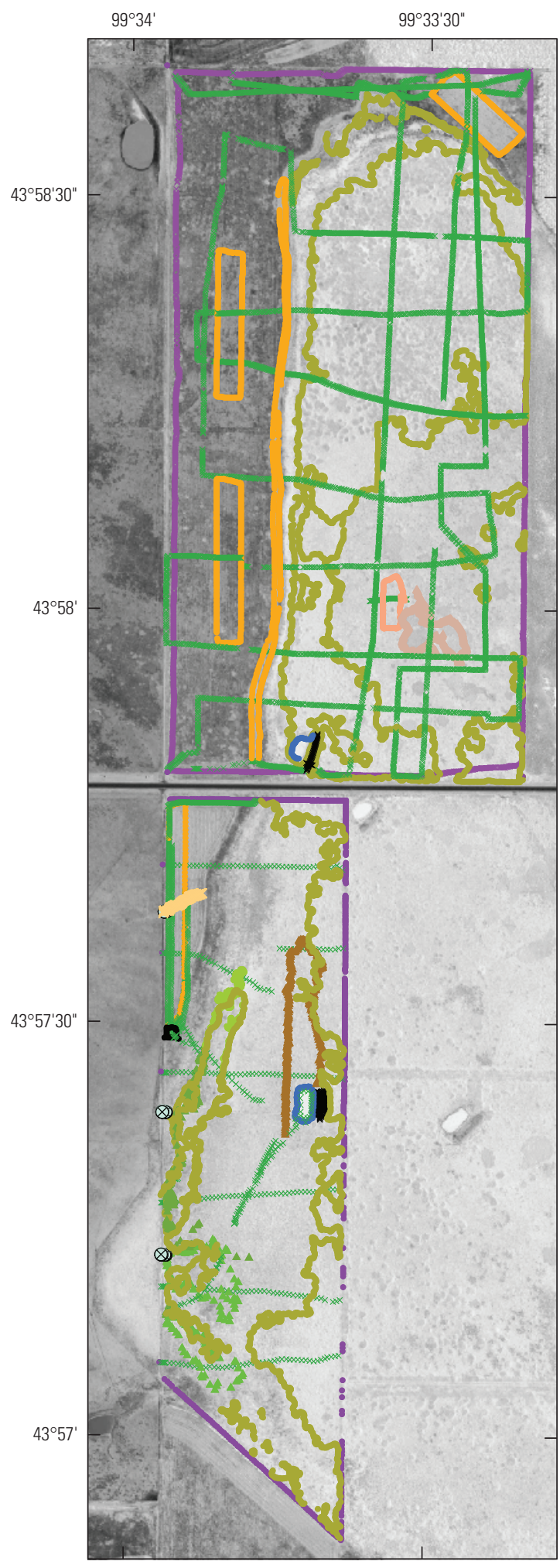

Base from National Agricultural Imagery Program, 2010 National Wetlands Inventory, 2004

Albers Equal-Area Conic projection

North American Datum of 1983

Figure 5. Primary land, water, and vegetation features for the Potter Slough wetland parcel. 


\section{Ground-Survey Data}

A summary of the total area for each wetland parcel that was surveyed during 2012-13 and for areas of standing water bodies within each parcel is provided in table 4 . Table 4 also summarizes selected information from the NWI (U.S. Fish and Wildlife Service, 2014b) that was previously presented in table 2. Parcel areas within the surveyed wetland perimeters ranged from about 20 to 450 acres. Parcel areas for the Miller Pond and West Brule Community wetland parcels include large upland areas adjacent to the actual wetlands and thus are substantially larger than the wetland areas from the NWI. The Dorman Slough and Potter Slough parcels also include large upland areas, but the total parcel areas (table 4) are smaller than the NWI areas because of large wetland areas extending beyond the boundaries of tribal ownership. The unnamed slough parcel includes very little upland area, but the NWI wetland area (tables 2 and 4 ) extends well beyond the surveyed parcel. No NWI area is listed in table 2 or 4 for the Little Bend Wetlands, which were constructed after the NWI classification system was developed.

At the time of the ground surveys (2012-13), all six of the wetland parcels had at least one standing water body, as summarized in table 4. Several of the wetlands had flooded areas at the time of the ground surveys because of recent precipitation conditions or management practices. Because access was limited to tribally owned land and some parts of wetlands were flooded, the area of water bodies surveyed do not equal the areas described for freshwater ponds from the NWI (U.S. Fish and Wildlife Service, 2014b).

The GIS datasets for all of the surveyed wetlands are provided in the format of geodatabase feature classes in the appendix of this report. These GIS data were interfaced with (1) aerial imagery from the National Agricultural Imagery Program and (2) data from the NWI (U.S. Fish and Wildlife Service, 2014b) to develop figures showing primary features for each wetland or wetland complex. These figures are presented throughout the remainder of this section, along with descriptions of relevant information for each wetland or wetland complex.

Dorman Slough (fig. 2) is a large wetland complex located just south of the Lower Indian Brule Reservation (fig. 1). The LBST owns a 325-acre parcel (table 4; about $0.5 \mathrm{mi}^{2}$ ) that includes the wetland and upland areas that were surveyed. The parcel contains two primary wetland areas that are connected by a drainage feature (connecting channel) near the center of the parcel. A constructed dugout is located about $900 \mathrm{ft}$ southwest of this drainage feature. The full extent of the Dorman Slough wetland complex extends about $1 \mathrm{mi}$ or more

Table 4. Areas for wetland parcels and selected wetland or water features, for wetlands investigated for this study.

$[<$, less than; --, not determined $]$

\begin{tabular}{|c|c|c|c|c|c|}
\hline $\begin{array}{l}\text { Name of wetland } \\
\text { or wetland area }\end{array}$ & $\begin{array}{l}\text { Parcel } \\
\text { area' } \\
\text { (acres) }\end{array}$ & $\begin{array}{l}\text { National } \\
\text { Wetlands } \\
\text { Inventory } \\
\text { area }^{2} \\
\text { (acres) }\end{array}$ & $\begin{array}{l}\text { Water } \\
\text { body area }^{3} \\
\text { (acres) }\end{array}$ & $\begin{array}{l}\text { NWI pond } \\
\text { area }^{4} \\
\text { (acres) }\end{array}$ & Generalized description of surveyed water body \\
\hline Dorman Slough & 325 & 474 & $<1$ & 6.88 & The only standing water present was within a single dugout. \\
\hline $\begin{array}{l}\text { Little Bend Wet- } \\
\text { lands }\end{array}$ & 20 & -- & 16 & -- & $\begin{array}{l}\text { Combined area inside three constructed wetlands (mainly dry } \\
\text { at time of survey). }\end{array}$ \\
\hline Potter Slough & 450 & 1,050 & $<1$ & 0.47 & $\begin{array}{l}\text { Standing water present in two dugouts (one each in north and } \\
\text { south parcels). Several other small, irregularly shaped areas } \\
\text { of standing shallow water were encountered, but edge of } \\
\text { water could not be accurately surveyed. }\end{array}$ \\
\hline $\begin{array}{l}\text { West Brule Com- } \\
\text { munity }\end{array}$ & 160 & 33.9 & $<0.01$ & 33.9 & $\begin{array}{l}\text { One small spring-fed pool in northeastern part of parcel. An } \\
\text { irregularly shaped area of shallow water was present in the } \\
\text { wetland south and east of the lagoons, but the edge of water } \\
\text { could not be accurately surveyed. }\end{array}$ \\
\hline
\end{tabular}

\footnotetext{
${ }^{1}$ Total area within surveyed perimeter of wetland parcel, including uplands, 2012-13.

${ }^{2}$ Total wetland area from the National Wetland Inventory (U.S. Fish and Wildlife Service, 2014b).

${ }^{3}$ Total area of surveyed water bodies in wetland parcel, 2012-13.

${ }^{4}$ Area classified as freshwater pond in the National Wetland Inventory (U.S. Fish and Wildlife Service,2014b).
} 
to the north and west of the area that was surveyed. Cattails covered large parts of the wetland, and food plots planted with sorghum were surveyed around the periphery of the wetland in several locations.

The Little Bend Wetlands area (fig. 3) is a complex of three constructed wetlands within two parcels totaling about 20 acres (table 4). This area is located on a land mass that is nearly surrounded by the "Little Bend" of the Missouri River (fig. 1). The wetlands were constructed by the LBST for recreational and agricultural purposes. Berms of topsoil were constructed on the downslope side of a field to contain water. Under typical climatic scenarios, the wetlands are mostly dry, but all three wetlands can be supplied with groundwater from a well located near the largest (southeastern) wetland. A combination of above- and below-ground pipes is used to convey water from the well to the three wetlands. The areas surrounding and inside the berms are planted to corn or other crops in the spring. In the fall, water from the well is used to flood the

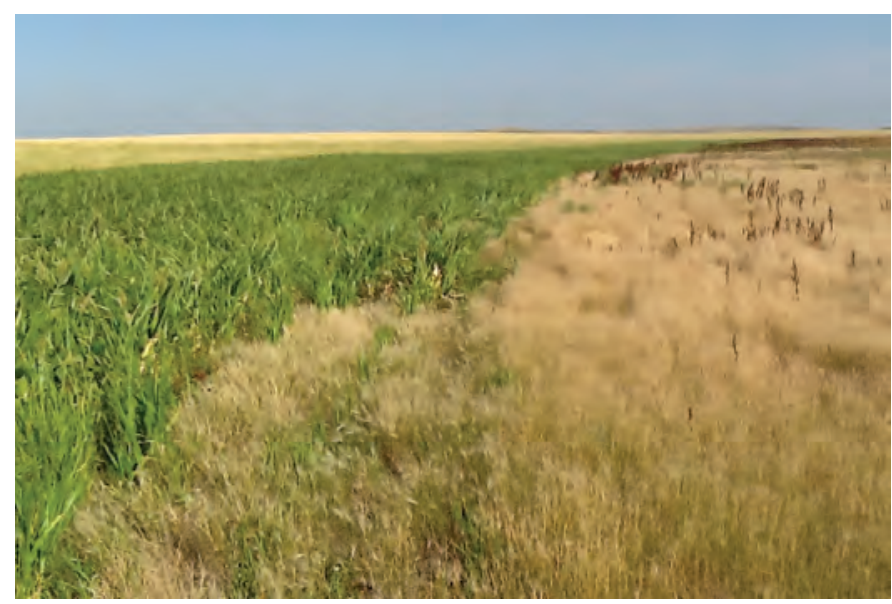

View of wetland vegetation (right) and food plot (left) at Dorman Slough.

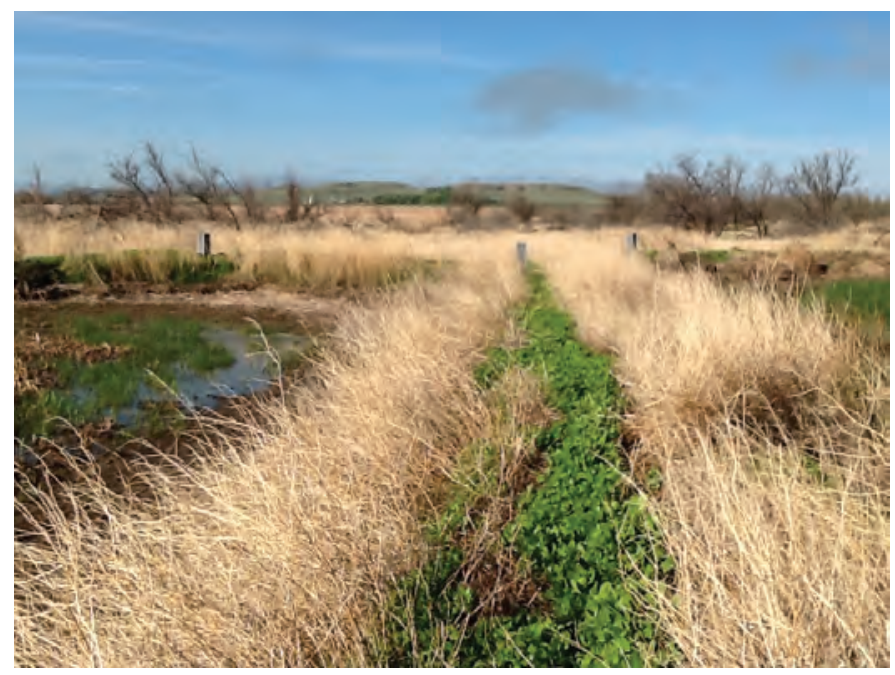

Inlet/outlet control structure at Little Bend Wetlands area. standing crops within the berms, providing waterfowl habitat and feeding areas. Outlet control structures also are present on each of the three wetlands to allow the water to be maintained at various levels and to control the area inundated.

Miller Pond (fig. 4) is a wetland area within a 240-acre parcel (table 4) located in the south-central part of the reservation (fig. 1). Water from a well along the northwestern edge of the wetland is used to permanently maintain wet conditions throughout the wetland area. Two berms (spoil piles) flanking an excavated dugout stand above the typical water level along the northeastern edge of the wetland. A food plot that provides food and cover for wildlife was surveyed along the eastern edge of the parcel, and larger crop fields also are present southwest of the dirt access road leading to the pond. A small stock dam is located in a draw about $1,000 \mathrm{ft}$ north of Miller Pond (extent inset, fig. 4). Although cross-section points were collected on the dam itself, the area of impounded water is much smaller than Miller Pond and was not selected by the LBST for extensive mapping within this parcel.

The Potter Slough wetland parcel (fig. 5) consists of two tracts totaling 450 acres (table 4 ) that are separated by State Highway 47 (fig. 1). These wetlands are referred to as the North and South Potter Sloughs, and they are part of a larger wetland complex, parts of which have non-tribal ownership. Both wetland areas have excavated dugouts with berms. Depending on rainfall patterns, the areas containing water may be limited to the dugouts, or the whole area may be inundated. Food plots are located in various areas around the wetland periphery.

The unnamed slough (fig. 6) is in a 50-acre parcel (table 4) located in Stanley County, near the northwestern boundary of the reservation (fig. 1). The unnamed slough is part of a larger wetland, most of which lies within the Fort Pierre National Grasslands (not shown), and is managed by the U.S. Forest Service. The survey focused primarily on the wetland area, but included a small part of the surrounding upland area. A small dugout is located in the southern end of

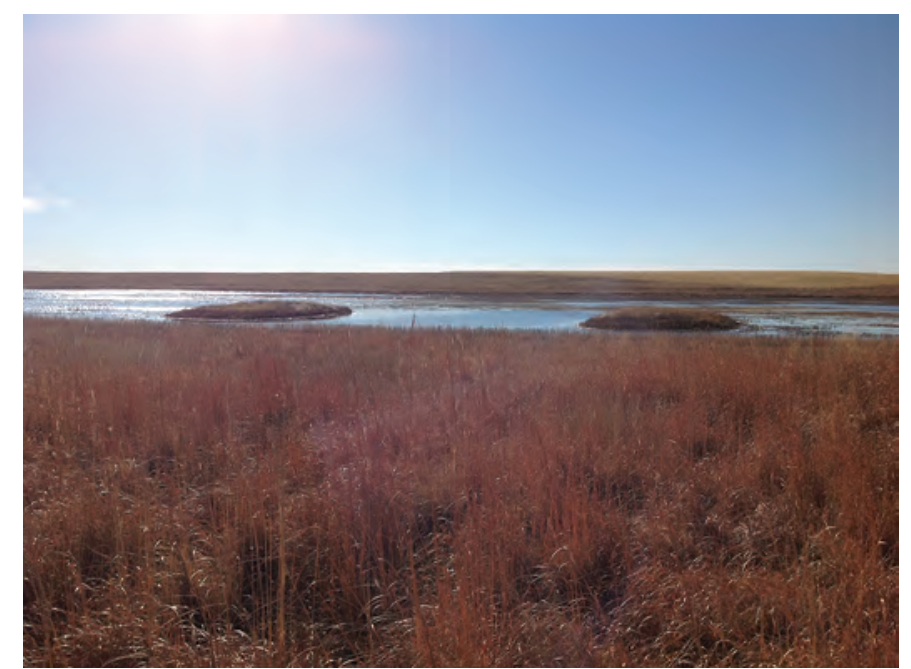

View of inundated dugout berms at Miller Pond wetland area. 
Full extent of unnamed slough

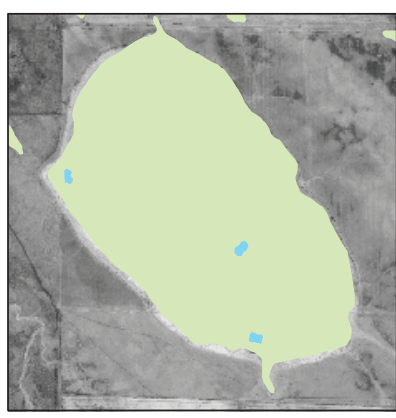

EXPLANATION

Freshwater pond

EXPLANATION

- Cattail edge

Cross section

Cross section on spoil pile

Curly dock edge

Dugout edge

- Fenceline

- Spoil pile edge

- Upland vegetation edge

Extent of points mapped

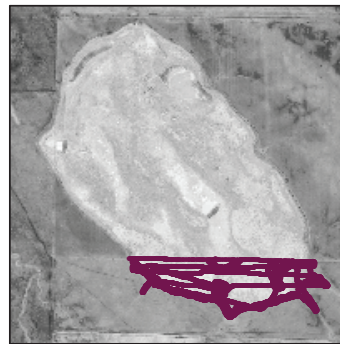

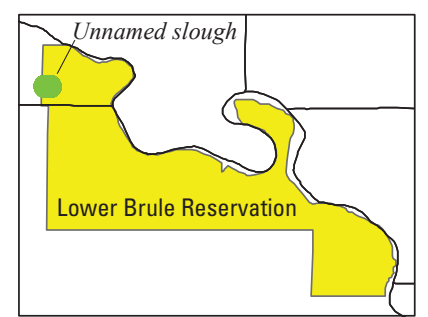

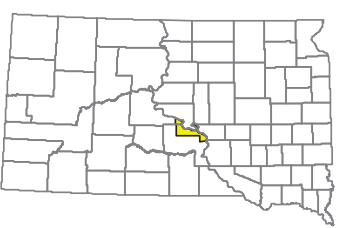

$100^{\circ} 04^{\prime} 20^{\prime \prime}$

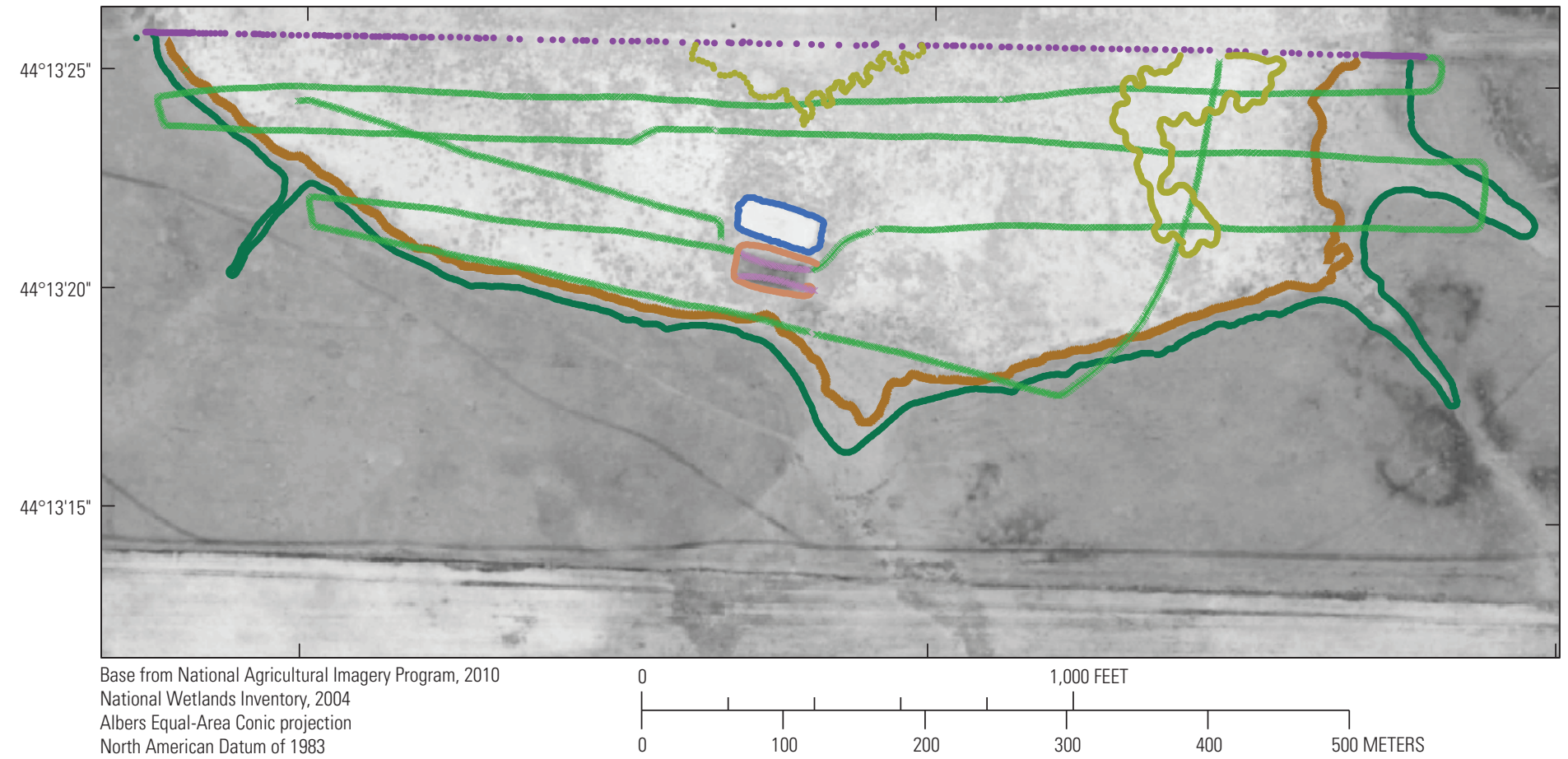

Figure 6. Primary land, water, and vegetation features for the unnamed slough wetland parcel. 


\section{Ground-Survey Data}

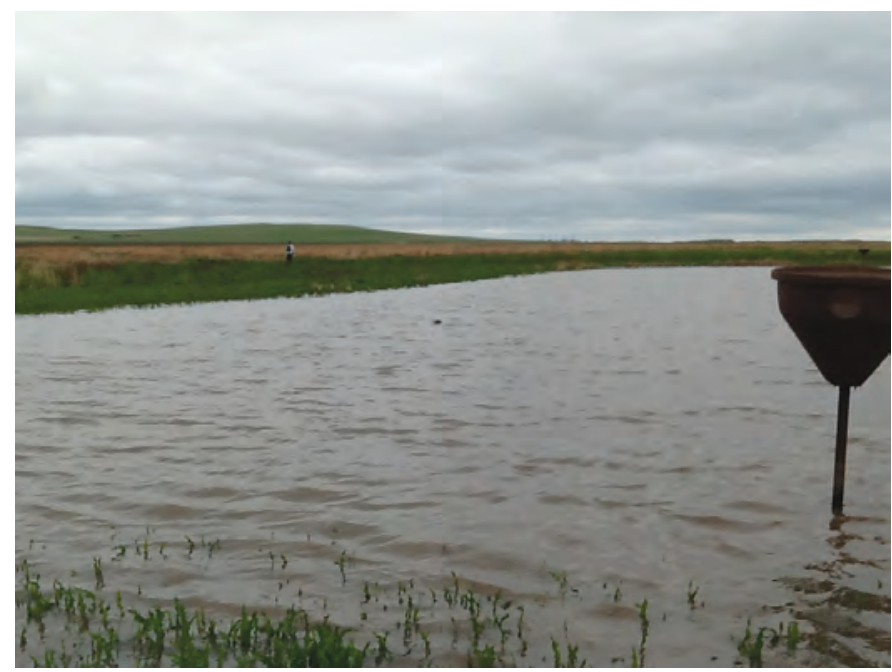

Dugout at South Potter Slough. Object in right foreground is goose nesting tub. the wetland. Most of the area within, or slightly beyond the "curly dock edge" (fig. 6) was at least partially (and erratically) inundated during the mapping effort; therefore, mapping of a distinctive water's edge was not feasible.

A distinctive perimeter was not surveyed for the West Brule Community wetlands area (fig. 7). Instead, several irregularly shaped areas that wrap around the western part of the community of West Brule (fig. 1) were surveyed. These areas collectively totaled about 160 acres (table 4). Although the West Brule wastewater lagoons are located in the area, they were not included in the mapping or water-quality sampling efforts. Several of the smaller wetlands indicated in the NWI were not discernible in the field survey, including one within a residential area of West Brule, and several in agricultural areas. A large, deep gully is located along the northern edge of the surveyed area. The lower parts of this gully had numerous springs, several of which flow to a very small (less than 0.01 acre; table 1) shallow pool at the northwestern edge of a thicket in the northeastern part of the surveyed area.

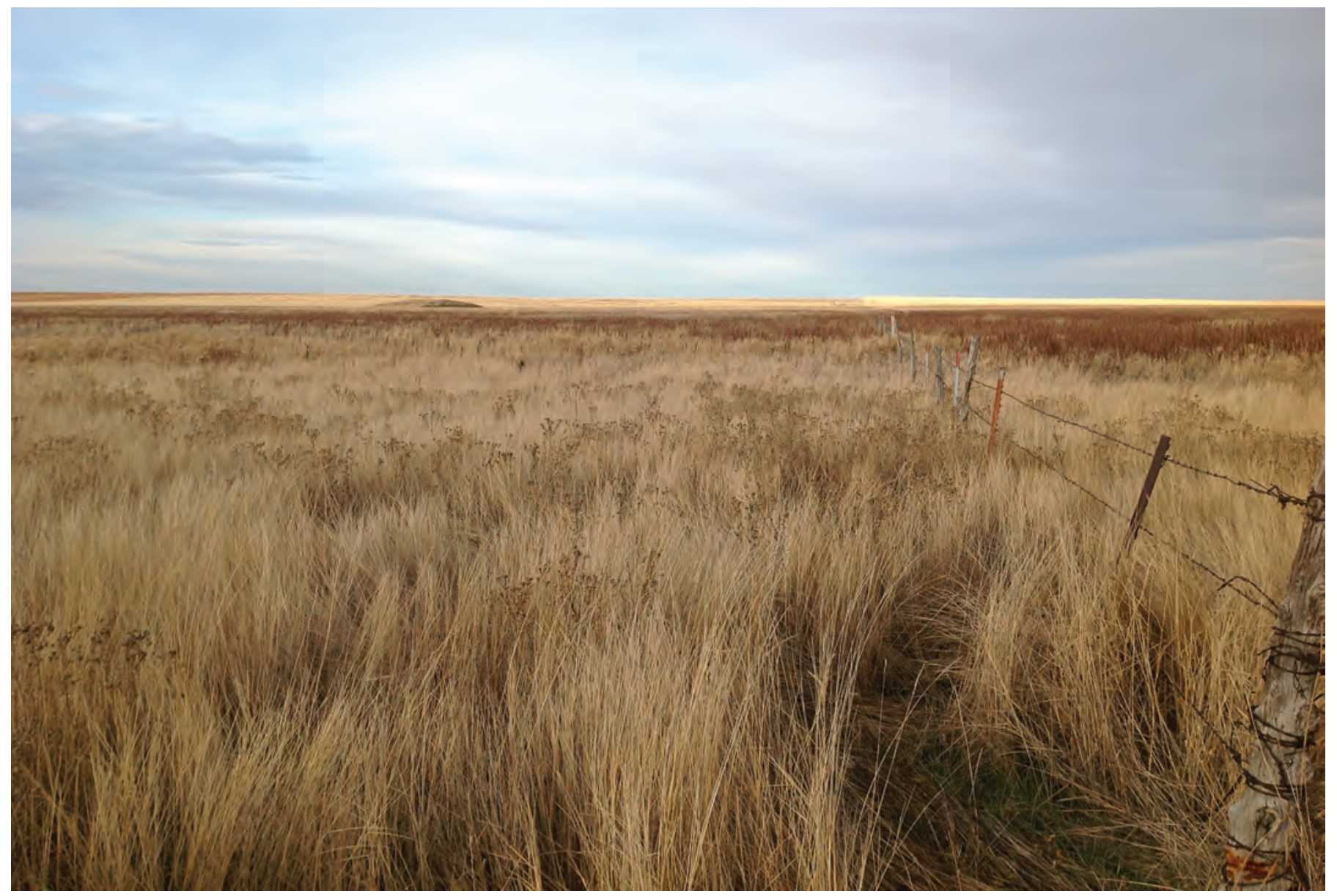

View of unnamed slough wetland area. 

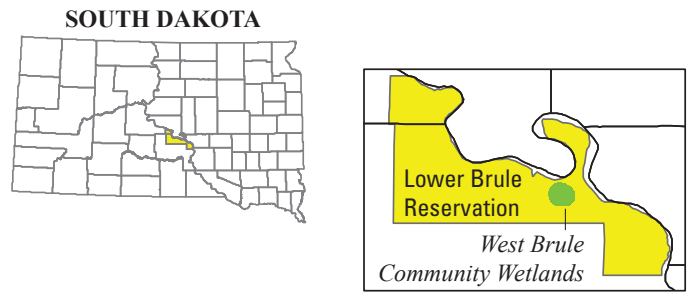

Full extent of wetlands

Extent of points mapped
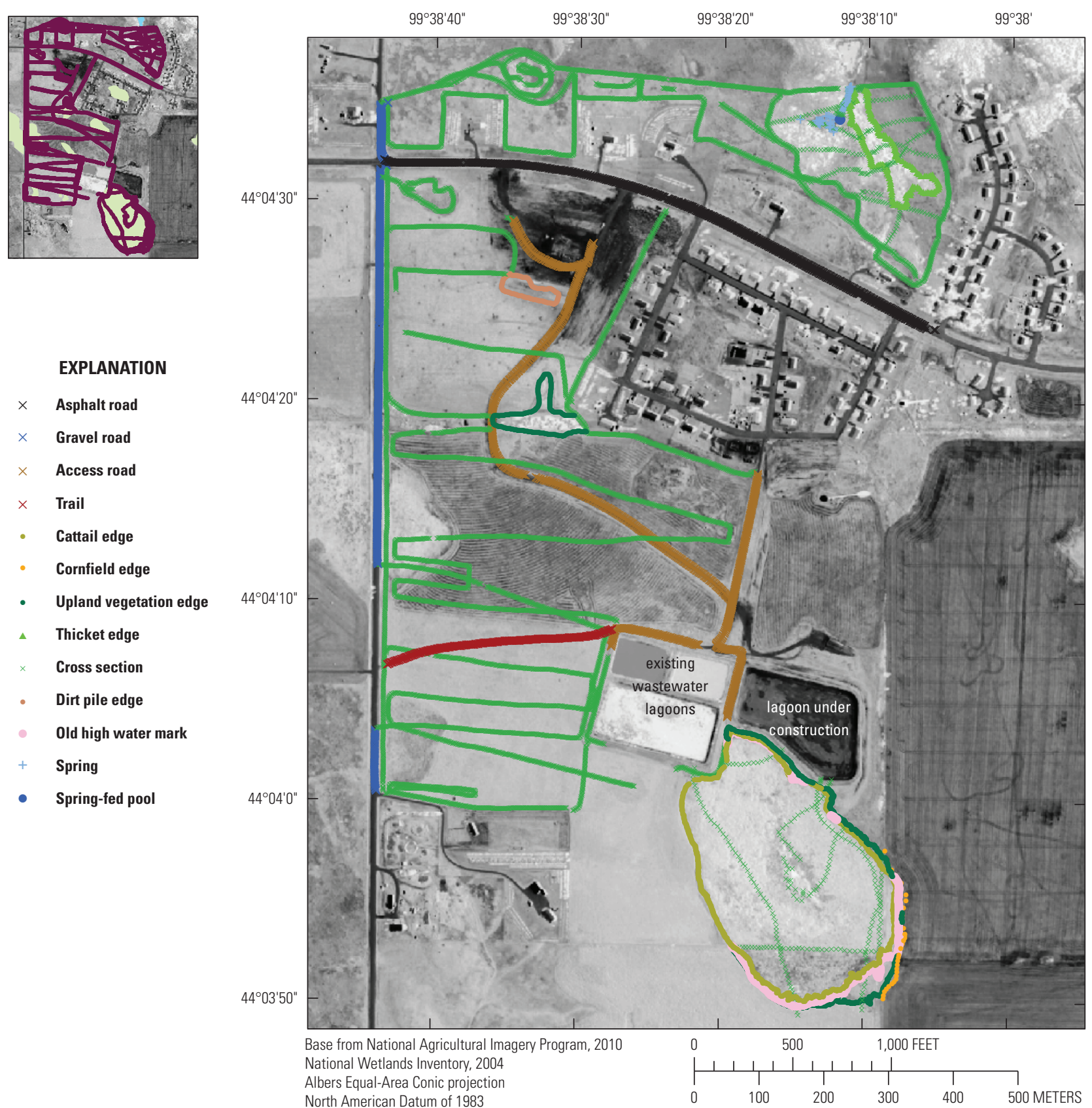

Figure 7. Primary land, water, and vegetation features for the West Brule Community wetland area. 


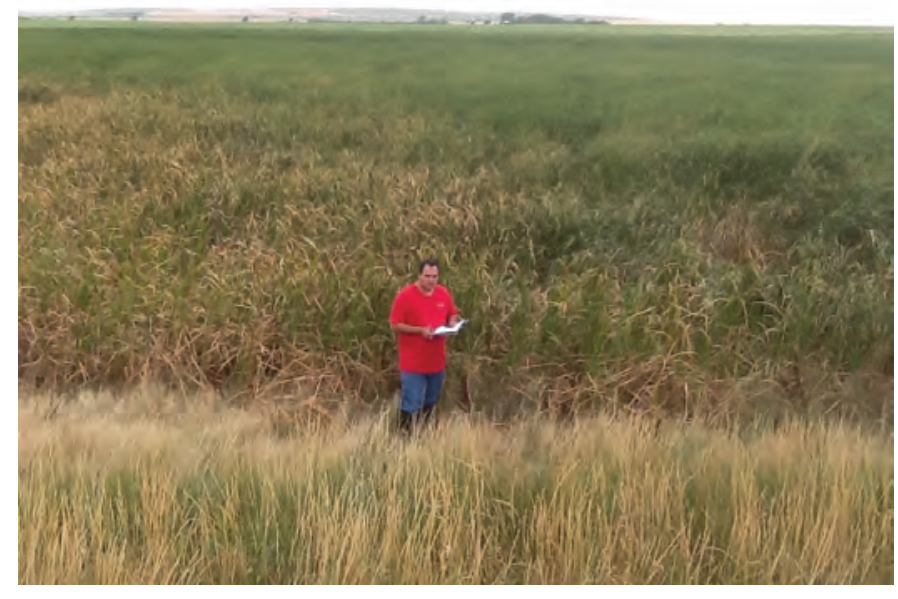

\section{Water-Quality Data}

Water-quality samples were collected during November 13-14, 2013, from five locations at four of the selected wetlands (table 3): Dorman Slough, Miller Pond, Potter Slough (north and south locations), and the south wetland of Little Bend Wetlands (South Little Bend Wetland). The unnamed slough was not sampled due to flooding conditions, and the West Brule Community wetlands were not sampled because of insufficient water in the wetlands of interest.

Physical properties of barometric pressure, $\mathrm{pH}$, specific conductance, water temperature, and turbidity were measured in the field, with results shown in table 3. Samples also were collected and analyzed for a limited suite of inorganics, metals, nutrients, and suspended sediment. Results are shown in table 3, along with results for a replicate sample for qualityassurance/quality-control purposes collected at the north Potter Slough location.

Specific conductance values for Miller Pond and South Little Bend Wetland (the two wetlands fed by flowing wells) are much larger (in some cases by an order of magnitude or more) than for the other sampling locations (table 3 ). Concentrations of dissolved calcium, sodium, and sulfate also are much larger for Miller Pond and South Little Bend Wetland than for the other sampling locations, which is consistent with the specific conductance values.

Concentrations of dissolved silica were about 50 percent larger in the replicate sample than in the environmental sample. This replicate sample indicates larger uncertainty for silica than for most other constituents, but increases confidence that the silica concentrations for the north and south Potter Slough samples truly are substantially greater than for the other three sampling locations. Similarly, the dissolved iron concentration was about twice as large in the replicate sample as in the environmental sample, which indicates relatively large uncertainty for dissolved iron concentration; however, increases confidence that the environmental sample actually is about an order
Lower Brule Sioux Tribe staff surveying wetland area southeast of West Brule Community.

of magnitude larger than for the other sampling locations. Water-quality data collected for this study can be accessed from the USGS National Water Information System waterquality database (U.S. Geological Survey, 2015) by using the USGS station identification numbers presented in table 3 .

\section{Summary}

Numerous lakes, ponds, and wetlands are located within the Lower Brule Indian Reservation. Wetlands are an important resource providing aquatic habitat for plants and animals, and acting as a natural water filtration system. Several of the wetlands on or near the reservation are of particular interest because of high recreational use by hunters and fishermen. Information on the physical and biological integrity of these wetlands was needed to provide a base-line reference when planning for future water management needs. A reconnaissance-level study of selected wetlands on and near the Lower Brule Indian Reservation was completed in 2012-13 by the U.S. Geological Survey in cooperation with the Lower Brule Sioux Tribe using ground surveys and water-quality analyses. Ground surveys of six wetland areas (Dorman Slough, Little Bend Wetlands, Miller Pond, Potter Slough, an unnamed slough, and West Brule Community wetlands) were completed to map land, water, vegetation, and man-made features of the selected wetland areas using real-time kinematic global navigation satellite systems equipment. Data layers of the mapped features at each wetland are provided in a geodatabase format. Water samples were collected from four of the selected wetlands. Two separate waterbodies were sampled at one of the wetlands for a total of five sampling locations. Water samples were analyzed for physical properties, selected inorganics, metals, nutrients, and suspended sediment. Concentrations of calcium, sodium, and sulfate were greater at the two wetland sites fed by ground water, compared to the wetland sites fed by surface runoff. 


\section{References Cited}

Edwards, T.E., and Glysson, G.D., 1999, Field methods for measurement of fluvial sediment: U.S. Geological Survey Techniques of Water-Resources Investigations Report, book 3, chap. C2, 89 p. [Also available at http://pubs.usgs. gov/twri/twri3-c2/.]

Fishman, M.J., and Friedman, L.C., 1989, Methods for determination of inorganic substances in water and fluvial sediments: U.S. Geological Survey Techniques of WaterResources Investigations, book 5, chap. A1, 545 p. [Also available at http://pubs.usgs.gov/twri/twri5-a1/.]

Francis-Meador-Gellhaus, Inc., Consulting Engineers, 1978, Water resource inventory, Lower Brule Indian Reservation, Lower Brule, South Dakota, Phase I, The water resource base: Rapid City, South Dakota, Francis-Meador-Gallhaus, Inc., $54 \mathrm{p}$.

Francis-Meador-Gellhaus, Inc., Consulting Engineers, 1980, Water resource inventory, Lower Brule Indian Reservation, Lower Brule, South Dakota, Phase II: Rapid City, South Dakota, Francis-Meador-Gallhaus, Inc., 92 p.

Guy, H.P., 1969, Laboratory theory and methods for sediment analysis: U.S. Geological Survey Techniques of WaterResources Investigations, book 5, chap. C1, 58 p. [Also available at http://pubs.usgs.gov/twri/twri5c1/.]

Howells, L.W., 1974, Geohydrology of Crow Creek and Lower Brule Indian Reservations, South Dakota: U.S. Geological Survey Hydrologic Investigations Atlas HA-499, 2 sheets.

La Rocque, G.A., Jr., 1966, General availability of groundwater and depth to water level in the Missouri River Basin: U.S. Geological Survey Hydrologic Investigations Atlas HA-217, 2 sheets, scale 1:2,500,000.

National Geodetic Survey, 2014, OPUS - Online Positioning User Service: accessed February 5, 2014, at http://www.ngs. noaa.gov/OPUS/about.jsp\#about.

Ogle, K.A., 1995, Water-resources appraisal of the Lower Brule Indian Reservation in central South Dakota: U.S. Geological Survey Water-Resources Investigations Report 95-4116, 93 p., accessed July 30, 2014, at http:// pubs.er.usgs.gov/publication/wri954116.
Rieger, B.A., Higgins, K.F., Jenks, J.A., and Kjellsen, M.L., 2006, Demographics of western South Dakota wetlands and basins: Brookings, South Dakota, South Dakota State University Report B748, 124 p. [Also available at http:// pubstorage.sdstate.edu/AgBio_Publications/articles/B748. pdf.]

Rydlund, P.H., Jr., and Densmore, B.K., 2012, Methods of practice and guidelines for using survey-grade global navigation satellite systems (GNSS) to establish vertical datum in the United States Geological Survey: U.S. Geological Survey Techniques and Methods, book 11, chap. D1, 102 p. with appendixes, accessed April 17, 2014, at http://pubs. usgs.gov/tm $/ 11 \mathrm{~d} 1 /$.

South Dakota Agricultural Statistics Service, 2011, South Dakota County Profiles: accessed July 23, 2015, at http:// www.nass.usda.gov/Statistics_by_State/South_Dakota/ Publications/Annual_Statistical_Bulletin/2011/ab11092c. pdf.

Topcon Positioning Systems, 2007, HiPer Ga/Gb operator's manual: Topcon Positioning Systems, Incorporated, variously paginated.

U.S. Environmental Protection Agency, 1989, Method 507Determination of nitrogen- and phosphorus-containing pesticides in water by gas chromatography with a nitrogen-phosphorus detector, revision 2.0: accessed on January 21,2015 , at http://water.epa.gov/scitech/methods/cwa/ bioindicators/upload/2007_11_06_methods_method_507. pdf.

U.S. Fish and Wildlife Service, 2014a, National Wetlands Inventory [overview]: accessed on October 3, 2014, at http://www.fws.gov/wetlands/NWI/Overview.html.

U.S. Fish and Wildlife Service, 2014b, National Wetlands Inventory [wetlands mapper]: accessed on August 11, 2014, at http://www.fws.gov/wetlands/Data/Mapper.html.

U.S. Geological Survey, 2006, Collection of water samples (ver. 2.0): U.S. Geological Survey Techniques of WaterResources Investigations, book 9, chap. A4, September 2006, accessed January 2, 2015, at http://pubs.water.usgs. gov/twri9A4/.

U.S. Geological Survey, 2015, USGS water-quality data for South Dakota: U.S. Geological Survey National Water Information System, accessed July 8, 2015, at http:// waterdata.usgs.gov/sd/nwis/qw/. 


\section{Appendix 1. Geodatabase for Wetlands Surveyed on or near the Lower Brule Indian Reservation in South Dakota, 2012-13}

The geographic information system (GIS) datasets for the six surveyed wetlands (table 2) on or near the Lower Brule Indian Reservation in South Dakota are provided as individual feature classes within a single geodatabase in this appendix. Each feature class contains the GIS point data for the primary features (such as vegetation, water, roads, berms, and food plot boundaries) for each wetland complex surveyed during 2012-13 and shown in figures 2-7, and metadata describing the files contained in the geodatabase. The geodatabase is provided at http://water.usgs.gov/GIS/dsdl/ds949_LBWetlands_gdb.zip. Individual metadata files for the six wetlands surveyed can be accessed through the geodatabase or by using the following links:

- http://water.usgs.gov/GIS/metadata/usgswrd/XML/ds949_dorman.xml (Dorman Slough),

- http://water.usgs.gov/GIS/metadata/usgswrd/XML/ds949_little_bend.xml (Little Bend Wetlands),

- http://water.usgs.gov/GIS/metadata/usgswrd/XML/ds949_miller.xml (Miller Pond),

- http://water.usgs.gov/GIS/metadata/usgswrd/XML/ds949_potter.Xml (Potter Slough),

- http://water.usgs.gov/GIS/metadata/usgswrd/XML/ds949_unnamed.xml, unnamed slough, and

- http://water.usgs.gov/GIS/metadata/usgswrd/XML/ds949_west_brule.xml (West Brule Community wetlands). 
Publishing support provided by: Rolla Publishing Service Center

For more information concerning this publication, contact: Director, USGS South Dakota Water Science Center 1608 Mountain View Road

Rapid City, South Dakota 57702 (605) 394-3200

Or visit the South Dakota Water Science Center Web site at: http://sd.water.usgs.gov/ 


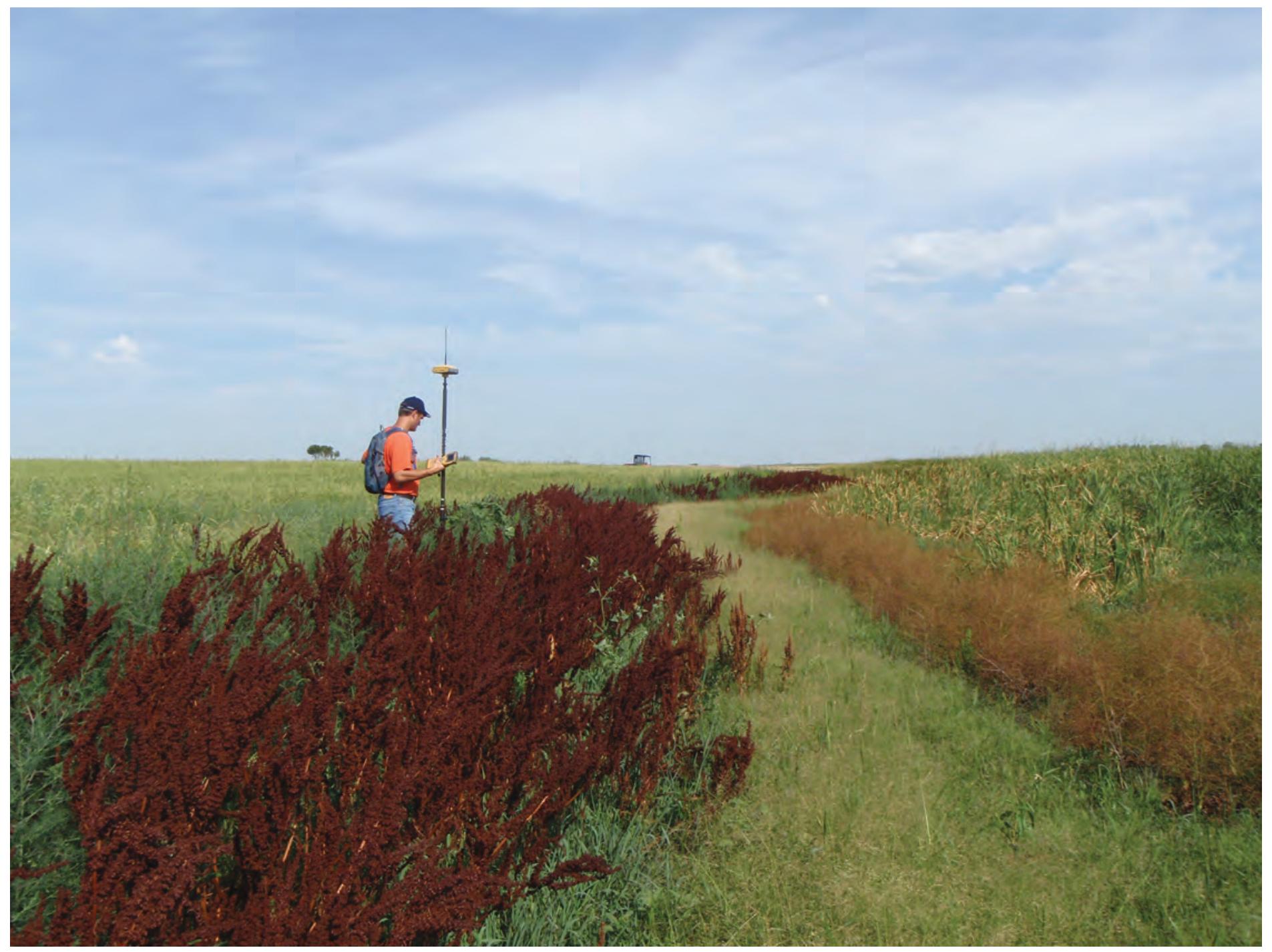

Above. USGS hydrologist surveying distinct vegetation bands in wetland area south of West Brule Community.

Back cover photograph. View of North Potter Slough showing dense stand of curly dock, with muskrat huts and cattail stand in the background. 


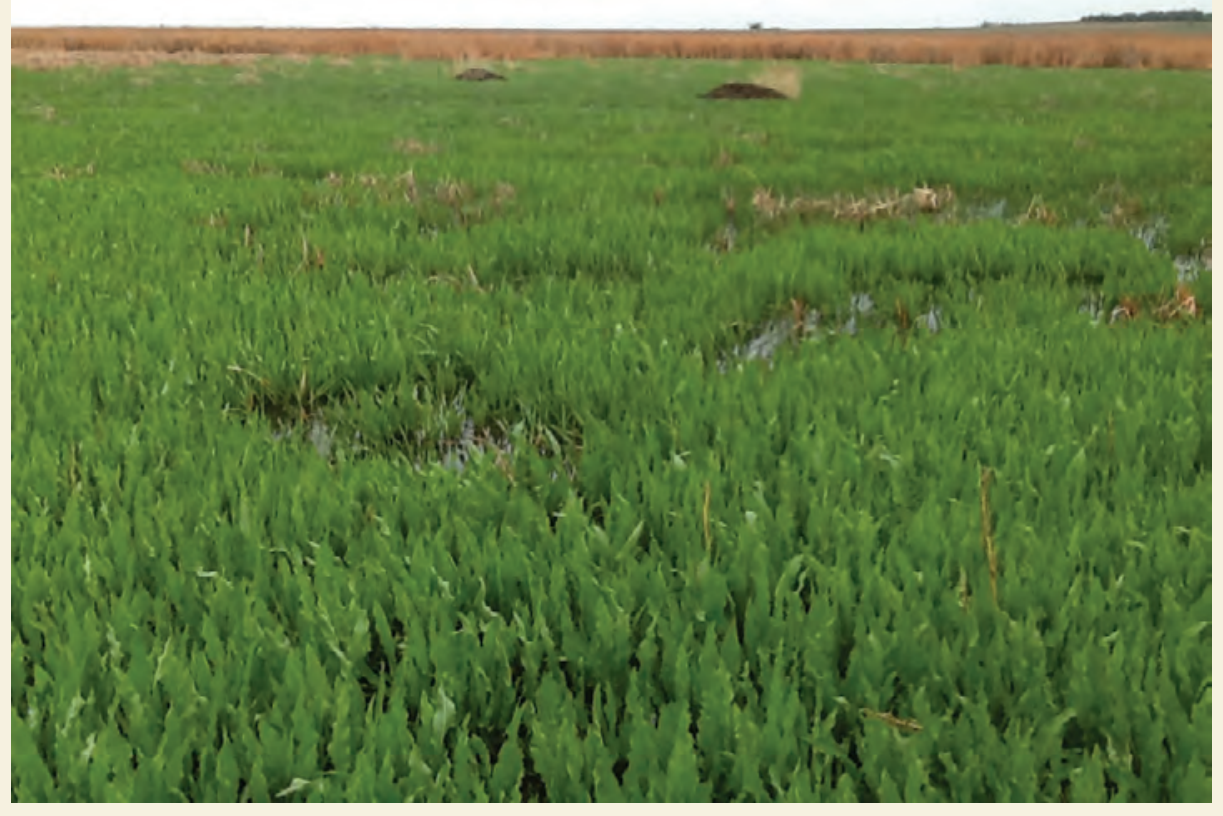

